\title{
Ethnoveterinary Practices of Medicinal Plants and Non-plant Remedies Used in Animal Health Management in Dawuro Zone, Southern Ethiopia
}

Tegegn Dilbato Dinbiso ( $\square$ dilbatot@gmail.com )

Ambo University College of Agriculture and Veterinary Science https://orcid.org/0000-0002-7408-1013

Tadele Tolesa Tolosa

Jimma University College of Agriculture and Veterinary Medicine

Feyissa Deressa Begna

Jimma University College of Agriculture and Veterinary Medicine

\section{Research}

Keywords: Dawuro zone, Ethnoveterinary practices, Animal health management, Medicinal plants, Non-plant remedies

Posted Date: October 22nd, 2020

DOI: https://doi.org/10.21203/rs.3.rs-94568/v1

License: () (1) This work is licensed under a Creative Commons Attribution 4.0 International License. Read Full License 


\section{Abstract}

Background: Ethnoveterinary medicine is frequently used for treating various livestock diseases by many different ethnic groups in Ethiopia. To this end, the indigenous knowledge on medicinal plants and non-plant remedies has not been systematically documented and studied in the Dawuro zone. Therefore, a community based cross-sectional study design was conducted from November, 2017 to September, 2018 in order to identify and document medicinal plants and non-plant ethnoveterinary practices in Dawuro zone, Southern Ethiopia.

Methods: Relevant ethnoveterinary data was collected from purposively selected 115 key informants using semi-structured questionnaire, focus group discussions, observations and field guided walk methods. The obtained data was analyzed using descriptive statistics, quantitative ethnobotanical methods and T-test and significantly test was set to $p<0.05$. The plants claimed having medicinal value were collected and botanically identified.

Results: The study revealed 103 plant species belong to 47 families and 11 non-plant remedies used to manage 36 different livestock ailments. Family Asteraceae accounted for $11.5 \%$ of the total species recorded. The majority of plants $(56.2 \%)$ were harvested from wild habitat. Herbs (33.8\%) were the main source of medicine followed by tree $(30.6 \%)$. Leaves $(43.6 \%)$ and roots $(27.5 \%)$ were the main plant parts used while pounding was the major form in remedy preparation. The highest Informant Consensus Factor (0.83) value was scored for the diseases of reproductive system. Cyphostema sp., Calpurina aurea and Pentas schimperiana were showed the highest Fidelity Level (100\%) to treat diseases of reproductive system, ectoparasites, and emaciation and bone broken as plant materials whereas Bear faeces, sharp hot iron or wire/knife, and salt were non-plant remedies used as treatment, respectively. Azadirachta indica was the most preferred species to treat blackleg and also with highest use-value (UVs $=0.25)$.

Conclusion: The study revealed that the local community of the study areas was used with a rich of indigenous knowledge of ethnoveterinary medicinal plants. The loss of valuable medicinal plant resources of the area calls for urgent and coordinated actions to develop conservation strategy.

\section{Background}

Livestock industry provides for a major source of livelihood for many people worldwide in providing milk, meat, skin, manure and traction, particularly the rural poor in developing countries [1]. In Ethiopia, the economic benefits from livestock production remains low due to prevailing diseases which are among the principal bottlenecks of livestock performance and cause of high economic losses to resource poor farmers [2, 3, 4]. Modern veterinary services are not well developed, and the modern drug availability is inadequate to fight animal diseases in Ethiopia [5, 6]. According to Wabe et al. [7] the majority of livestock keepers in Ethiopia are far away from animal clinic stations. The inadequate funding at the national level for the prevention and control of animal diseases adds to the burden, especially among pastoralists who live in the remote arid and semi-arid lowland parts of the country. The studies of Edwards et al. [9] and Yirga et al. [10] estimated that the traditional remedies are sometimes the only source of therapeutics for nearly $90 \%$ of livestock in Ethiopia of which $95 \%$ are plant origin.

The indigenous people of different localities in the country have developed their own specific knowledge of plant resource uses, management and conservation [15]. In the same way, Ethiopia has a glorious tradition of health care system based on plants, which dates back to several millennia (Regassa, 2013). Ethiopian farmers and pastoralists rely on traditional knowledge, practices and plants to control livestock diseases [12, 13], and have used traditional medicines for many centuries due to cultural acceptability, efficacy against certain diseases and economic affordability [14]. The study carried out by (Mesfin and Obsa, 1994) reported that cattle owners in Ethiopia have long been aware of serious diseases such as desta (rinderpest), aftegir (FMD), abasenga (anthrax), abagorba (blackleg), gendi (trypanosomosis) and diseases caused by internal and external parasites, and of the zoonotic nature of diseases such as anthrax and rabies. Before the introduction of modern veterinary practice, traditional healers were usually the only people approached to attend to these livestock diseases. The various traditional practices included prevention of diseases, recognition of toxic plants, surgical intervention and crude vaccination methods.

On the other hand, some of the non-plant materials reported to be used by the Fullani pastoralists include wood ash, honey, oils, kerosene, kaolin, potassium, local soap, and spent engine oil which they believe are effective in ethnoveterinary management. They use spent engine oil in the management of wounds, kerosene for foot rot, and local soap as disinfectant in animals (Alhaji and Babalobi, 2015).

The studies of Guschin et al. (2015) pointed out the impact of antimicrobial resistance is considerable with treatment failures associated with multidrugresistant bacteria and it has become a global concern to public health, and the effectiveness of modern pharmacotherapy is still limited by the cost of treatment (Kalayou et al. [8]. Therefore, developing a socially acceptable and effective remedy from inexpensive resources that can complement modern medicine would be an attractive option (Kalayou et al., 2012).

However, traditional veterinary medicine like all other traditional knowledge systems is handed down orally from generation to generation and it may disappear because of rapid socio-economic, environmental, technological changes and as a result of cultural heritage under the guise of civilization (Manoj et al., 2012), and few written records of ethnoveterinary were encountered (Wanzala et al., 2005; Kefalew and Sintayehu, 2017). Similarly, in many cases, individuals who are knowledgeable in traditional practices usually try to keep the knowledge secret and remain unwilling to openly teach to others. This is considered as a problem causing a loss of knowledge to the country, because such traditional peoples are becoming fewer and fewer in number (Gebrezgabiher et al., 2013; Lulekal et al., 2014). According to Belayneh et al. (2012) the studies conducted on the traditional remedies used in animal health care in Ethiopia are inadequate when compared with the multiethnic cultural diversity and the diverse flora of Ethiopia. The greatest concentrations of medicinal plants are found in the south and southwestern parts of the country following the concentration of biological and cultural diversity.

Moreover, the loss of valuable medicinal plants due to population pressure for settlement, agricultural expansion, which is aggravated by deforestation, burning forest, overgrazing and over harvesting is widely reported by different researchers in Ethiopia (Berhan and Dessie, 2002; Lulekal et al., 2014; Fenetahun

Page $2 / 23$ 
and Eshetu, 2017; Kebebew and Mohamed, 2017; Kefalew and Sintayehu, 2017). Thus, concerted ethnoveterinary research plays a vital role to document information on plants and related indigenous knowledge for conservation and sustainable utilization in study area. Such documents are important to define and maintain cultural identity of the people, establishing people-centred natural resource management and potential for development of novel drugs stated by Lulekal et al. (2014).

To the best of our knowledge there has been no systematic study conducted on the use of ethnoveterinary medicinal plants and non-plant remedies in the livestock health management in the Tocha, Mareka and Loma districts of Dawuro zone. Therefore, the present study was conducted in order to identify and document indigenous knowledge of the people on ethnoveterinary medicinal plants and non-plant remedies in management of animal health problems in the Dawuro Zone.

\section{Methods \\ Description of the Study Area}

The study was conducted from October, 2017 to September, 2018 in Dawuro zone, which is one of the 14 zones of Southern Nation Nationalities and Peoples Regional State (SNNPRS). The total surface area of the zone is estimated to be 4,436 square km which shares $4.07 \%$ of the total area of the region. It is bordered with the Oromia region in the northwest, Kembata Tembaro zone in the northeast, Wolaita zone in the east, Gamo Gofa zone in the south, and Konta Special district in the west. Tarcha is the capital town of the zone that is about $486 \mathrm{~km}$ southwest of Addis Ababa across Shashemene and $413 \mathrm{~km}$ across Hosanna, but $491 \mathrm{~km}$ across Jimma, $319 \mathrm{~km}$ away from Hawassa, the capital town of Southern Ethiopia and $144 \mathrm{~km}$ from Jimma [20]. The present study was conducted in three selected districts of Dawuro zone: namely, Tocha, Loma, and Mareka representing similar agro-climatic zone (lowland to highland) presented in (Figure 1).

Tocha district is situated about $528 \mathrm{~km}$ north east of Addis Ababa at $6^{0} 97^{\prime}-7^{0} 25^{\prime}$ north of latitude and $36^{0} 81^{\prime}-37^{0} 14^{\prime}$ east of longitude with an elevation ranging from 501-3000 meters above sea level. The total human population of the district is 141,470 and this is distributed in rural (130, 393) and urban (11, 077) areas. The mean annual temperature ranged from 15.1-25 ${ }^{\circ}$ Cand the mean annual rain fall ranged from 1401-1800 millimeter. Mareka is located at $6^{0}$ $97^{\prime}-7^{0} 21^{\prime}$ latitude North and $37^{0} 1^{\prime}-37^{0} 26^{\prime}$ longitude of East and altitude ranges from 1401-1800 meter above sea level. It has a total human population of about 161,621 (male and female were 83,399and 78,222), respectively. Loma district lies between $6^{0} 58^{\prime}-7^{0} 07^{\prime}$ North of latitude and $36^{0} 93^{\prime}-37^{0} 43^{\prime}$ East of longitude with an elevation ranging from 501-3000 meters above sea level. The average minimum and maximum temperature were 15.1 and $27.5^{\circ} \mathrm{C}$ with the mean annual rain fall ranges 1401-1800 millimeter [20].

Dawuro zone has endowed with enormous and diversified land features. Due to the geological activities of ancient period, major physical features like chain mountains, ups and downs, low reliefs characterize the zone, which all have important for recreational value. The highest altitude is "Tuta" in the Tocha district with extreme of 2852 masl located to the southwestern direction. The area possessed in dega, w/dega and kola agro-ecological zones. About $41 \%$ of the zonal land is lies under woyna dega (midland), kolla (lowland) covers about $38 \%$ and dega (highland) constitutes $21 \%$ of the total agro-ecological zones. The diversified climate, topography, waters and forest resources in the zone have attributed a wide range of environments for supporting varieties of fauna and flora. Due to the existence of favorable climatic condition and forest resources, Dawuro zone is habitat for wildlife species of mammals, reptiles and birds. Vegetation is very important for maintenance of ecological balance. Most of the vegetation in the zone consists mainly broad-leafed forest like Olea europaea L. subsp. Cuspidate (Wall. ex G.Don) (Weira), Juniperus procera (Tid), Podocarpus falcatus (Thunb.) Mirb. (Zigba), Hagnia abyssinica (Koso), Prunus africana (Hook. f) Kalkm. (Tikur inchet), Arundinaria alpine (Bamboo), etc. above all has good potentiality in bamboo tree, which one of the essential forest resources for the development of furniture industry (DZFEDD, 2017).

\section{The status of veterinary services in the study area}

People of the study area give great value for their animal healthcare. The community expressed the value of their animal health by using different traditional animal healthcare systems. The local people exploit their shared knowledge in order to manage different animal health problems at home by using different medicinal plants in found their vicinity and non-plant remedies before looking for other options regardless of the type of ailment and its severity. These homemade traditional herbalists are called "Wogaa D'aliya Eranchchaa" or Hilanchcha" in local language which translated as traditional practitioner.

The livestock population is significant. The zone has an estimated 1,277,482 heads of cattle, 646,704 sheep, 466,280 goats, 41,327 horses, 70,810 donkeys, 70,551 mules, and 970,263 poultry. According to the Zone Livestock and Fisheries Development Department, there are about 4 animal health clinics and 17 health posts in the zone, which are being run by 240 animal health professionals (4 Doctors of Veterinary Medicine, 200 animal health professionals and 2 animal health technicians) [22]. This was found insufficient to provide proper health services for a total of more than 3,543,417 heads present in the zone. Surprisingly, these clinics were poor in their facilities. In addition, this livestock sector faced various problems like inadequate funding, lack of skilled man power, lack of veterinary infrastructures like standardized veterinary clinic, laboratory, and heath posts. As the zone size and livestock population, the health facilities do not match and unable to support this major economic sector. Various animal diseases remain among the principal constraints of livestock health and production in the study area.

Due to this reasons, the local people in area have long been dependent on the ethnoveterinary practices accessed from their vicinity and non-plant original experiences to manage various animal health problems. 


\section{Study Design}

A community based cross-sectional study design was conducted with individual survey to assess and document the current status of the indigenous knowledge of community about medicinal plants and non-plant remedies in the ethnoveterinary practices. Ethnoveterinary data was collected from the community by using semi-structured questionnaires, supplemented by an in-depth interview with the herbalists, and field observations was conducted. Specimen vouchers have given on the spot for each plant species and later identify using taxonomic keys in the relevant volumes of the flora of Ethiopia.

\section{Sampling Method and Sample Size}

For this study, 14 kebeles were selected purposively based on the wide use of ethnoveterinary practices and availability of traditional healers. Selection of informants were performed according to [23] who stated that when recording indigenous knowledge controlled by ethnobotanical healers or by certain social groups, the choice of key informant is vital. A total of 115 key informants (107 males and 8 females): 48 informants from Tocha district, 34 informants from Loma district, and 33 informants from Mareka district were purposively selected for ethnoveterinary data collection. The selections of the informants were carried out with the help of Districts and local governmental bodies, and community elders. The selection criterion of informants was mainly based on their rich indigenous knowledge and long-term experience of utilization of plants from different agro-ecology of the study area.

\section{Ethnoveterinary Data Collection}

Ethnoveterinary data was collected from November, 2017 to September, 2018. The face-to-face interview was made by using pre-tested semi-structured questionnaires prepared in English and was translated into "Dawurotsuwaa" local language. Ethnoveterinary plant samples were collected in blooming stages annually with the objective of collecting plant specimens during the respective flowering seasons. Semi-structured questionnaire interviews addressed questions regarding name, age, gender, level of education, occupation, and religion background of each informant. The face-to-face and individual semistructured interviews included local names of medicinal plants, ailments treated, habit of the species, marketability, sources (wild/cultivated or both), parts used, other ingredients or additives (if any), methods of preparation, dosage formulation, routes of administration, noticeable side effects of remedies, use of antidotes for side effects, taboos/beliefs related to collection and restriction on use of plants, source of knowledge, ways of indigenous knowledge transfer, and non-plant remedies were recorded. Each informant was separately interviewed in their local languages in order to keep the secrecy of their indigenous knowledge.

In addition, 14 focus group (one focus group per kebeles with average number of 6-10 participants) discussions were undertaken to gain further information on medicinal plants knowledge of the community and prove the reliability of the data collected through semi-structured interviews [23, 24].

Field trips were made with local herbalists for the collection of the reported medicinal plants. Voucher specimens of medicinal plants were collected on the field with the help of traditional healers and field assistants. Collected medicinal plants were dried, numbered, pressed and labeled were brought to the Ethiopian Herbarium for further botanical identification. Specimen identification and confirmation were undertaken by using Flora of Ethiopia. Finally, the specimens were deposited at the National Herbarium (ETH) in Addis Ababa University.

\section{Ethical Consideration}

This study was approved by the Ethical and research review Board of Office of Jimma University, College of Agriculture and Veterinary Medicine. A brief discussion was held with the selected Districts governmental bodies and informants prior to data collection in explaining the main objective of the study. In addition, the consent of each respondent was asked verbally to participate in the study. This was done in order to acknowledge informants' cooperation in preserving the traditional knowledge of the study area and build their confidence for providing reliable information. Consequently, the confidentiality of their traditional property owners was completely maintained during data collection.

\section{Data Management and Analysis}

Ethnoveterinary data were entered and coded using MS Excel, and was transferred to the Statistical Package for Social Sciences Software (SPSS) versions 20. A descriptive statistical method such as percentage, frequency and tables were employed to analyze and summarize the data on medicinal plants of species and families of ethnoveterinary medicinal plants, their growth forms, parts harvested; methods of remedy preparation and routes of administration.

Preferences ranking of ethnoveterinary plant species used to treat the commonly reported livestock ailments in the study area were ranked by adding the values/scores of preferences given by respective informants so as to identify the most-preferred medicinal plant species to treat the most frequently reported disease type in the area following the relevant standard methods [23, 24].

Informant Consensus Factor (ICF) values [25, 26] were calculated to determine the most important livestock ailment categories in the Districts and identify potentially effective medicinal plant species in respective disease categories. Accordingly, reported traditional remedies and corresponding livestock ailments occurring in the zone were categorized into six disease categories and the Informant Consensus Factor values were obtained by computing number of use citations in each disease category (Nur) minus the number of times species used (Nt), divided by the number of use citations in each category minus one.

$\mathrm{ICF}=\underline{\mathrm{Nur}-\mathrm{Nt}}$

Nur-1 
Where, Nur = number of use reports from informants for a particular plant-use category; $\mathrm{Nt}=$ number of taxa or species that are used for that plant use category for all informants.

In this study, the fidelity level analytical approach was also used in evaluating the plants and non-plant remedies in the study area. The fidelity level is mathematically expressed as FL $=\mathrm{Ip} / \mathrm{lu} \times 100$, where $\mathrm{FL}$ is the fidelity level of each plant or non-plant material, Ip is the number of informants who mentioned that a plant or non-plant material has specific ethnoveterinary uses against a particular disease condition, and lu is the total number of key informants who independently suggested that the same plant or non-plant material has any ethnoveterinary uses [26, 27].

According to [28] the use-value (UV) index was used to calculate the citation of plants during interviews. To calculate the use-value of one species to an informant $\left(U V_{\text {is }}\right)$ has used the formula $U V_{\text {is }}=\Sigma U_{s i} / n_{\text {is, }}$, where $U_{s i}$ is the number of uses mentioned by the informant for the species and $n_{\text {is }}$ the total number of interviews with the informant. For this work $n_{\text {is }}$ is always 1 (one), it was done only one interview per informant, and t-test and one way ANOVA with significantly test was set to $\mathrm{P}<0.05$, was used to evaluate significant differences in the mean of medicinal plants reported by different genders, ages and education levels.

\section{Results}

\section{Socio-demographic Characteristics of Respondents}

A total of one hundred fifteen (115) key informants were interviewed; of which one hundred seven (93\%) were males and eight (7\%) were females. The age of male informants with a mean age of $5.34 \pm 2.44$ years and female informants with a mean age of $5.63 \pm 3.98$ years. The number of plants reported by females was ranging from two to eight and males from 2 to 29 medicinal plants. The average number of medicinal plants reported by males (5.53 \pm 3.74$)$ was the same as females $(5.88 \pm 2.10)$, and the difference was not significant $(p>0.05)$. The average number of plants reported by young to middle aged informants $(23 \leq$ 39) was $5.34 \pm 2.44$, old informants $(40 \leq 90)$ were $5.63 \pm 3.98$, and the difference was not significant $(p>0.05)$. The average number of plants reported by illiterate informants was $4.69 \pm 2.43$, a literate (completed at least primary education) was $6.57 \pm 4.50$, and the difference was significant ( $p<0.05$ ). The difference among the study districts and different agro-ecology in the number of medicinal plants reported by each informant was not significant ( $p>0.05$ ). Concerning occupation, none of the informants practice traditional medicine as their only source of income. Most of the healers are farmers.

\section{Indigenous Knowledge and Diversity of Ethnoveterinary Plants in Dawuro zone}

The present study showed the rich knowledge of medicinal plants in Dawuro zone that was indicated by the number and diversity of medicinal plants reported. In this study, ethnoveterinary knowledge was acquired from different sources which include parents, friends and elders. Oral transfer of traditional knowledge of medicinal plants $(90.4 \%)$ was the major source of knowledge acquisition; only $1.7 \%$ acquired knowledge through documenting and $7.8 \%$ kept secret their knowledge. The comparison between use frequency of medicinal plants and synthetic drugs showed that up to $50.4 \%$ of informants had frequently use the plants especially for certain diseases which do not respond to modern drugs like mastitis and listeriosis; just $45.2 \%$ answered that they use alternatively (both medicinal plants and modern drugs), and $4.3 \%$ confirmed that they depends on the synthetic drugs.

The present study revealed that the local communities of Tocha, Mareka and Loma districts utilize a total of 103 ethnoveterinary medicinal plants belonging to 47 families and 11 non-botanical remedies for the treatment of 36 different livestock ailments. The reported medicinal plants and their respective indications, use-value, preparation and parts used for preparing the ethnoveterinary medicines as presented in Table (2 and 3$)$. Among all the families, Asteraceae was found to be dominant (13 species, $11.5 \%$ ) being in use as ethnoveterinary practices in the study area followed by Fabaceae ( $8.8 \%$ ) and Solanaceae (8.4\%), respectively.

Regarding to the type of plants of ethnoveterinary importance, there majority of herbs (33.8\%) followed by tree (30.6\%), shrub (27.5\%) and climbers (8.1\%). About $56.2 \%$ of medicinal plants were harvested from the wild environment, whereas $34.3 \%$ from cultivation and the remaining $9.5 \%$ were claimed to be collected from both wild and cultivated sources.

\section{Types of Livestock Ailments and Traditional Diagnostic Methods}

A total of 36 veterinary ailments were identified in the study area for which informants reported to use one or more medicinal plant species to treat specific livestock ailments which categorized into infectious, non-infectious (grain overload, bloat and constipation), diseases of respiratory system, diseases of reproductive system, ectoparasites infestation and other ailments (bone broken, snake biting, trauma, poising and emaciation and fattening) according to [29]. A majority of (63.6\%) veterinary ailments claimed by the community to be present in the Districts belong to infectious, followed by other ailments (13.3\%) as presented in (Figure 2). Out of a total ailments, blackleg is the most common livestock disease locally called "S'okka" (18.0\%) followed by trypanosomosis "Goloba" (15.1\%) (Table1).

Table 1 Major livestock health problems in the study area 


\begin{tabular}{|c|c|c|c|c|}
\hline Ailments treated & Local name & $\begin{array}{l}\text { № of } \\
\text { respondents }\end{array}$ & $\%$ & Rank \\
\hline Blackleg & S'okkaa & 103 & 18.0 & 1 \\
\hline Trypanosomiasis & Gollobaa & 86 & 15.1 & 2 \\
\hline Emaciation & Gilk'aanne d'iikuwa & 37 & 6.47 & 3 \\
\hline Internal parasitism & Uluwa gus'uniya & 36 & 6.3 & 4 \\
\hline Anthrax & S’ilkiya & 32 & 5.6 & 5 \\
\hline Tick & Dank'uwa & 30 & 5.3 & 6 \\
\hline Bovine pastueriollosis & Miizzaa Shulullaa & 29 & 5.1 & 7 \\
\hline Leech & Ulletsaa & 26 & 4.6 & 8 \\
\hline Diarrhea & Gusuwa & 19 & 3.3 & 9 \\
\hline Bloat, Hematuria /babesiosis & Shifiraaruwa/zaaguwa, Zuluwa/wuliwushshaa & 18 & 3.2 & 10 \\
\hline Foot and Mouth Disease & Maassiya & 16 & 2.8 & 12 \\
\hline Listeriosis & Biic'uwa hargiya & 14 & 2.5 & 13 \\
\hline Mastitis/evil eye & D’antsaa harggiya/Asayfiya & 13 & 2.3 & 14 \\
\hline Ovine pastueriollosis, Tsetse fly infestation & Dorsaa shulullaa, Gollobaa ahiya uduns'iya & 10 & 1.8 & 15 \\
\hline Coenurosis, Bone broken & Dorsaa Yiic'uwa, Mek'etsaa méuwa & 8 & 1.4 & 17 \\
\hline $\begin{array}{l}\text { Dermatophilosis and Lumpy Skin Disease, Lice, } \\
\text { Rabies }\end{array}$ & Galbaa harggiya, C'uuchchaa, Wora kanaa hargiya & 5 & 0.9 & 19 \\
\hline $\begin{array}{l}\text { Arthritis, retained placenta, Snake bite, Newcastle } \\
\text { Disease }\end{array}$ & $\begin{array}{l}\text { Karshshuwaa, Guyyebaa/Du'aa is'uwa, Shoshshaa satsaa, } \\
\text { Kuttuwa hargiya }\end{array}$ & 4 & 0.7 & 22 \\
\hline $\begin{array}{l}\text { African Horse Sickness, Epizootic lymphangitis, Eye } \\
\text { disease, Wound }\end{array}$ & Paraa harggiya, Paraa bollaa d'uussaa, Ayfiya harggiya, Maytsaa & 3 & 0.5 & 25 \\
\hline $\begin{array}{l}\text { Kidney problem/urine retention, Trauma/yolk, } \\
\text { Papillomatosis, Plant poising, Constipation, } \\
\text { Coccidiosis/Poultry }\end{array}$ & $\begin{array}{l}\text { Kilaahuwa harggiya or Sheeshsha is'uwa Sadiyan gakiya } \\
\text { qohuwan, Dad'd'uwa, Mitsaa marziya, Uluwa meluwa, Kuttuwa } \\
\text { gusuwa hargiya }\end{array}$ & 2 & 0.4 & 29 \\
\hline Grain overload & Katsaa darssi muussaa & 1 & 0.2 & 34 \\
\hline
\end{tabular}

\section{Applications of Ethnoveterinary Remedies}

Ethnoveterinary medicinal plants of the study districts were claimed to be applied for ailments affecting cattle, sheep, goats, equines, poultry, and dogs. The majority of the medicinal plants (81.55\%, 84 species) were found to be applied to treat one or more of the thirty-two (32) different cattle, sheep and goats' ailments. A relatively few numbers of ethnoveterinary species $(3.88 \%, 4$ species) were mentioned to be used against poultry and equine ailments and the remained $14.56 \%$ (15 plant species) are used for all animal species in common including dogs. Regarding to treated animal species, the highest ethnoveterinary medicinal plants used for $89 \%$ cattle followed by $3.35 \%$ sheep, $3.2 \%$ equines, $2.2 \%$ poultry, $0.9 \%$ goats and $0.5 \%$ dogs, respectively.

Most ethnoveterinary medications (93.4\%) were claimed to comprise remedial parts of a single medicinal plant. However, $1.9 \%$ was prepared using formulations from two species and $4.7 \%$ more than two plant species. Amongst all plants used as medicine, the highest proportion of species was claimed to treat blackleg (18.0\%), trypanosomiasis (15.1\%), emaciation and fattening (6.47\%) and internal parasitism (6.3\%). The highest number of multiple ethnoveterinary uses was recorded for Capsicum frutescens (treated against 12 ailments) and Croton macrostachyus and Lepidium sativum (10 ailments each) as presented in Table ( 2 and 3 ). Although different plant parts were reported to be used for treatment preparation by the community, commonly used plant parts are presented in Figure (3).

Methods of Remedy Preparation, Routes of Administration, and Dosages Variation and Side Effects

Concerning methods of treatment preparation, various methods were reported to be used in the districts based on type and severity of livestock diseases. Pounding the part in wooden or stone-made mortar and pestle, and homogenizing it with water is found to be the major method of preparation (77.88\%), followed by crushing (7\%) presented in Figure (4).

Traditional plant treatments are reported to be administered through oral, topical, nasal, fumes/smoking or auricular routes of the diseased animal. Oral application is reported to be the best-represented route of administration (72.35\%), followed by nasal (16.11\%), topical (9.64\%), 1.26\% fumes/smoking and $0.6 \%$ auricular routes. The result showed that traditional practitioners reported use of plastic jugs, glasses, bottles, cups, syringe, and gourd traditionally called 
"Buliyaa" to determine dosage for some medicinal preparations while others use a handful or counting like Solanum anguiv anguivi Lam and Eubolia schimperi, preparation to treat ailments. About $58.3 \%$ practitioners use approximately to treat their animals. This finding showed that no strictly standardized doses of herbal preparations as known for modern veterinary medicine was reported by traditional healers for any of the preparations used to treat livestock ailments in the area.

Apart from their ethnoveterinary use, most of the medicinal plants identified in the study area are used by the community for different purposes. In this study, medicinal plants have values other than their medicinal roles such as, $20.5 \%$ human disease treatment, $7.1 \%$ fire wood, $5.7 \%$ construction, $4.3 \%$ timber production, $21.8 \%$ animals fodder, $3.5 \%$ fence, $11.4 \%$ edible, $6.8 \%$ spices, and $19 \%$ other uses like agricultural tools; and soil and water conservation. About $93 \%$ of traditional practitioners reported that there is no taboos association in the use of medicinal plants while few herbalists (7\%) preferred days and time for plant collection like on Sunday and Wednesday, and at early morning without contact with any person.

\section{Informants Consensus Factor (ICF) and relative healing potential of medicinal plants}

Test of evaluation of ethnoveterinary medicinal plants six major livestock ailment categories were identified from the total 36 veterinary diseases reported in the Zone classified according to [29]. Highest Informants Consensus Factor (ICF) values were recorded for respiratory disease (0.83), infectious (0.78) and ectoparasites (0.74) categories presented in Table (4). In addition, highest plant use citation (57.34\%) was recorded for infectious diseases.

Table 4 Informant Consensus Factor (ICF) values of traditional medicinal plants for treating livestock ailments in Dawuro zone

\begin{tabular}{|lllllll|}
\hline № & Disease category & No. of plant sp. & \% of all species & Use citations & \% all use citations & ICF \\
\hline 1 & Non-infectious & 13 & 12.62 & 17 & 2.68 & 0.25 \\
\hline 2 & Infectious & 81 & 78.64 & 363 & 57.34 & 0.78 \\
\hline 3 & Respiratory disease & 11 & 10.67 & 17 & 2.68 & 0.375 \\
\hline 4 & Reproductive disease & 7 & 6.8 & 36 & 5.68 & 0.83 \\
\hline 5 & Ectoparasites & 24 & 23.3 & 89 & 14 & 0.74 \\
\hline 6 & Miscellaneous & 33 & 32 & 111 & 17.53 & 0.71 \\
\hline
\end{tabular}

ICF = Informant Consensus Factor

Concerning to Fidelity Level value, Cyphostema sp, Calpurina aurea and Pentas schimperiana showed highest fidelity level value (100\%) for reproductive disease, ectoparasite infestations, and fattening and broken bone category. Under the infectious therapeutic category, highest fidelity level value was recorded for Eucalphytus globules (91.67\%) and Croton macrostachyus (90.9\%) has also showed relatively high healing potential record under the wound and traumatic injuries disease category (Table 5).

Table 5 Fidelity level (FL) value of medicinal plants commonly reported against a given veterinary ailment category. 


\begin{tabular}{|c|c|c|c|c|c|c|}
\hline № & Scientific name & Local name & Therapeutic category & IP & IU & $\mathrm{FL} \%$ \\
\hline 1 & Azadirachta indica & Mimmiyaa mitsa & Infectious/Blackleg & 25 & 29 & 86.2 \\
\hline 2 & Aloe otallensis Baker & Godare utsa & Respiratory disease & 9 & 11 & 72.72 \\
\hline 3 & Cyphostema sp. & Higishsha d'aliya & Reproductive/mastitis & 22 & 22 & 100 \\
\hline 4 & Calpurina aurea & Maylluwa & Ectoparasites & 6 & 6 & 100 \\
\hline 5 & Dracaena steudneri Engler & Gegelluwa & Equine GIT parasite & 8 & 10 & 80 \\
\hline 6 & Croton macrostachyus & Anka & Wound and traumatic injury & 20 & 22 & 90.9 \\
\hline 7 & Ageratum conyzoides & Kirkissa & Diarrhea and dysentery & 9 & 11 & 81.81 \\
\hline 8 & Capsicum frutescens & Mis'imis'uwa & GIT parasitism & 14 & 16 & 87.5 \\
\hline 9 & Echinops kebericho & Burssa & Snake poising & 11 & 14 & 78.57 \\
\hline 10 & Eucalphytus globules & Botsa barzaafiya & Infectious/Blackleg & 22 & 24 & 91.67 \\
\hline 11 & Pentas schimperiana & Dawuridama/Dalbantsaa & Fattening and bone broken & 22 & 22 & 100 \\
\hline 12 & Eriosema sp. & Boshuwa & Infectious/Blackleg & 10 & 17 & 58.82 \\
\hline 13 & Vernonia amygdalina & Gara & Anti-trypanosomosis and tsetse fly control & 14 & 21 & 66.67 \\
\hline 14 & Justica schimperiana & Sanssalliya & Listeriosis and Coenurosis & 9 & 14 & 64.3 \\
\hline
\end{tabular}

$F L=$ the fidelity level, IP = the number of informants who mentioned that a plant has specific ethnoveterinary uses, IU = the total number of key informants

\section{Preference Ranking of Ethnoveterinary Plants}

Preference ranking exercise with 15 randomly selected informants for medicinal plants that were reported to be used against Blackleg, the most frequently reported livestock disease under the infectious disease category, showed that Azadirachta indica and Eucalphytus globules were most-preferred species to treat the reported disease (Table 6).

\section{Non-plant Remedies and Factors Contributing to Use of Ethnoveterinary Medicine in the Study Area}

In this study, the communities depend on traditional medicines due to primary healthcare system during outbreak and ailments rise, easy availability of medicinal plants, comparative effectiveness, lack of modern drugs and veterinary infrastructures, distance to clinic stations, affordability and low cost, and resistant diseases that cannot be respond to modern drugs such as mastitis and listeriosis according to informant explanations. The traditional non-botanical ethnoveterinary practices used in managing other cattle disease conditions are presented in (Table 7).

Table 7 Fidelity level (FL) value of non-plant remedies used by the community to treat livestock diseases 


\begin{tabular}{|c|c|c|c|c|c|c|}
\hline $\mathrm{S} / \mathrm{N}$ & Materials & Local name & Ethnoveterinary uses & IP & IU & $\begin{array}{l}\mathrm{FL} \\
(\%)\end{array}$ \\
\hline 1 & Hyena faeces, wood ash & $\begin{array}{l}\text { Babark'iya shi'aa, } \\
\text { bidintsaa }\end{array}$ & Listeriosis, evil eye & 8 & 10 & 88 \\
\hline 2 & Kerosene & Laambbaa & Tick expulsion & 6 & 8 & 75 \\
\hline 3 & Dear feaces & Babantsaa shi'aa & Blackleg & 5 & 5 & 100 \\
\hline 4 & Hot wire/knife & $\begin{array}{l}\text { Ho'oo } \\
\text { biraata/Mashaa) }\end{array}$ & Blackleg & 10 & 10 & 100 \\
\hline 5 & Porcupine meat & K'us's'ariya ashhuwa & Blackleg & 17 & 19 & 89.5 \\
\hline 6 & Milk & Maatsaa & Plant poising & 6 & 6 & 100 \\
\hline 7 & Fermented kocho (Ensete ventricosum (Welw.) Cheesman) & C’aalaa unc'c'a & $\begin{array}{l}\text { Stomatitis, Foot and Mouth } \\
\text { Disease }\end{array}$ & 5 & 10 & 50 \\
\hline 8 & $\begin{array}{l}\text { Porridge and the end product of local } \\
\text { kocho (Ensete ventricosum (Welw.) Cheesman) }\end{array}$ & $\begin{array}{l}\text { Shendeerannee } \\
\text { Zaalima }\end{array}$ & $\begin{array}{l}\text { Antidotes, antitoxic for plant } \\
\text { poising }\end{array}$ & 8 & 9 & 88.9 \\
\hline 9 & Oil, soap & Zaayttiya & Blackleg, bloat & 4 & 6 & 66.7 \\
\hline 10 & Honey dew & Degeriya eesaa & Blackleg & 9 & 10 & 90 \\
\hline 11 & Salt & Mas's'inniya/as'uriyaa & $\begin{array}{l}\text { Mineral deficiency, fattening, } \\
\text { appetite promotion }\end{array}$ & 6 & 6 & 100 \\
\hline
\end{tabular}

\section{Discussion}

\section{Indigenous Knowledge and Diversity of Ethnoveterinary Plants of the Study Area}

The present study showed the rich knowledge of ethnoveterinary medicinal plants in Dawuro zone that was indicated by the number and diversity of plants reported. The results showed that there was no difference in the average number of plants reported either by female or male respondents indicated both men and women members of the community have good knowledge on medicinal plant use. This finding is disagrees with other studies conducted in the country $[30,31,32]$ who observed that men had more knowledge of plant usage because they are naturally selected during childhood to be apprentices of ethnoveterinary practices. In this study, the knowledge regarding the treatment of animal ailments did not show any difference between the age groups. In other studies, however, it was observed that the number of medicinal plants reported was increased with age, and the older informants reported more medicinal plants than younger individuals $[17,31,33,34]$. This could be related to a higher degree of cultural contact and experience of the elderly members with curative plants than that of younger members in the community.

The findings also showed that educational level is considered as a factor to determine the inheritance of indigenous knowledge, and conservation and sustainable use of medicinal plants. The indigenous knowledge regarding the treatment of animal ailments did show significant difference between levels of education. Illiterate informants reported significantly more medicinal plants than literate members. This might be oral transfer, influence of modernization and technological changes, and lack of curiosity by educated generations to acquire indigenous knowledge like their fore parents. This finding is in agreement with the previous studies of others in Ethiopia [35] and other world [26,36] who reported as majority of informants are illiterate while only few of them reached the high school diploma level.

Oral transfer and secrecy on acquisition of knowledge on ethnoveterinary practices within the study districts, most of the time-tested indigenous knowledge of the traditional herbalists passes away might also explain the decline of indigenous knowledge going down the generation ladder. This result agrees with other findings in Ethiopia $[13,34,37,38]$ and elsewhere in other countries $[1,33,39,40]$ share a similar concern on the knowledge gap down generations in different cultural groups.

According to informants, livestock keeping is one of the most important economic sources of rural community of study area as a major support to their livelihoods, crop production, transport, and for generating income to sustain life. The farmers of the area not only depend on plants to get fodder for their animals but also use different medicinal plants to treat various animal diseases. Results of this study showed that people in the Dawuro zone have longstanding indigenous knowledge on the use of medicinal plants to treat various livestock ailments. The deep-seated culture of plant use for successive generations might have played the role for a sentimental adherence of the community to ancestral medical traditions which are still held as highly valued heritage of the society.

The number and diversity of medicinal plants reported by informants revealed the rich traditional ethnoveterinary knowledge in Dawuro zone and the number of medicinal plants reported is more than the studies conducted in Ethiopia and other different parts of the world [2, 10, 13, 41, 42], in Brazil [17], South Africa $[43,44]$, Pakistan $[26,45]$, and India $[46,47]$. The millennia-old interaction of indigenous people in the area with in the vicinity available medicinal plants might have enabled them to develop an indigenous knowledge system best fit to select and use diverse curative medicinal plants to treat frequently occurring livestock diseases. The studies of [31] stated that knowledge on plant use is the result of many years of human interaction and selection on the most desirable and successful plants present in the immediate environment at a given time.

The present study revealed that best representation of ethnoveterinary species of family Asteraceae with 13 species has the highest species followed by Fabaceae, Lamiaceae and Euphorbiaceae, respectively in the study area. The wider utilization of this Asteraceaefamily might be due to its plenty in the study 
area or high bioactivity [26]. This finding was however different from that of [41, 48] who in an ethnoveterinary survey reported Solanaceae and Fabaceae family respectively the first level use. The difference among study might be related to the different dominant vegetation of the areas or might be associated with traditional beliefs of different cultures in using traditionally specific plants.

\section{Growth Habit, Source and Parts of Ethnoveterinary Plants Used}

The present finding showed that the most commonly used medicinal plants habit in the study area are utilization of herbs followed by trees in treatment preparation. The present finding was in contrast with other investigators [37, 49-52] who reported dominance of shrub species for ethnomedicinal preparation in Ethiopia. The variation might be related to different ethnolinguistic groups in the country could be attributed to the wide agro-ecological diversity and specific indigenous knowledge of different communities.

Results also revealed that the dominant practice of harvesting majority (56.2\%) of ethnoveterinary plants of Dawuro zone is from wild sources. This would indicate the degree of anthropogenic pressure exerted on wild plant resources of the area. Overdependence on wild resources together with reduction of the wild resources due to ever-increasing population pressure poses a threat to medicinal plant riches of the area. Comparable trends in overharvesting medicinal plants from uncultivated sources were also reported in other parts of [30, 31 37, 38, 53, 54], and in another place in Pakistan [45, 55], and Brazil [17]. In this study, the communities have less effort to cultivate medicinal plants in their home gardens and agricultural field rather, they go to nearby or far places and collect the plants.

The finding showed that leaves to be the most harvested plant parts followed by roots in the treatment preparation. This finding is in line with the results of other ethnomedicinal studies [17, 56-60].The first line choice of leave might be associated with traditional beliefs in communities about no difficulty of collection, preparation, and the main site of photosynthesis and are involved in a variety of physiological processes of plants and produce numerous secondary metabolites that could be a possible reason for their effectiveness and efficacy against animal health problems.

\section{Livestock Ailments, Treatment Preparation and Traditional Diagnostic Methods}

Identification of specific livestock ailment types in the area was found to be made based on indigenous knowledge on symptoms and corresponding livestock illnesses held in the memories of local people. Similar was found true in selecting medicinal plants which were thought to be most appropriate to manage different veterinary health problems.

Results also showed that leech infestation (4.6\%) is one of a challenge to livestock health in the study area during winter (Bega) and spring (Tseday) seasons. This might be related to have an annual life cycle of leeches. They breed in the spring; young leeches develop and mate in the spring of the following year. In addition, adult leeches can live for as long as 18 to 27 years [61]. On the other hand, traditional healers argued that reduction of different fresh water bodies (rivers and streams) in amount during dry season has low pressure that could not washed out leeches from water bodies which make favorable condition for multiplication. Thus, traditional healers use remedial plants to control leech infestations.

The dose administered often varied with the parts of the plant used and the methods of preparation. In this study, the majority of the treatments are taken orally as also reported earlier in other parts of Ethiopia [31, 52, 62]. In addition, the majorities of herbalists administer the preparations once or twice daily for three days or keep treating until the animal recovers if the disease is not acute like blackleg. The traditional herbalists have a clear understanding about the occurrence of certain outbreak diseases from other endemic diseases mainly characterized by lameness and shivering according to those interviewed (blackleg). In fact, this disease mentioned present in higher number or the symptoms are more noticeable. Based on distinctive clinical symptoms that sick animals shown, they immediately search for solutions to treat their animals. Full recovery is confirmed when the animals resume feeding and other physical activities. If animals do not respond to the treatments, they search for other alternatives like modern drugs.

Furthermore, treatments are given to the domestic animals with different vehicles like water, seed, flour, milk, and so forth, in the area. The use of these vehicles might be due to their enhancing potential of taste and medicinal properties of certain plant remedies. Physical manifestation of the diseased animal and visually confirmed degree of severity of illness are used to determine preparation doses to treat livestock ailments. Some traditional practitioners used a various unit of measurements such as plastic jugs, glasses, bottles, cups, syringe, and gourd locally called "Buliyaa" to measure dosage for remedial preparations while others reported to use a handful or counting like Solanum anguiv anguivi Lam. However, there is no strictly standardized dose of herbal preparations as known for modern veterinary medicine was reported by traditional healers for any of the preparations used to treat livestock ailments in the area. The same findings were also reported from other studies conducted at different parts of the world [17, 26, 45, 60, 63] who reported the lack of standardized doses in traditional prescriptions of livestock traditional medicine. The lack of precision and standardization has been cited as one of the most important shortcomings of the traditional healthcare system in Ethiopia [8, 31, 64, 65].

Due to lack of standardized doses of herbal preparations, traditional practitioners observed some symptoms of side effects of herbal preparations on their animals in the study area like shock and lacrimation. For instance, if high amount of Azadirachta indica and Solanum anguiv anguivi Lam. administered might cause noticeable side effects. However, no death cases were reported by the informants because they use different traditional antidotes like drinking and sprinkling cold water immediately to the body of animals especially head region, milk, porridge and the end product of traditional kocho fluid "Zaalima" to manage plant side effects. 
The observed diverse medicinal uses of plants in the area against various livestock ailments indicates presence of inherent curative property engraved within each medicinal plant which still plays an essential role for the production of relatively healthier cattle, sheep, goats, equines, chickens and dogs. The relatively high number of medicinal plants cited for treating cattle ailments may also be related to occurrence of more diseases affecting cattle populations in the area. Presence of largest use of ethnoveterinary plants for treating cattle ailments was also reported for other cultural groups in the country [31]. Two plant species: namely Sida scimperiana and Artemisia annua L. are used for treatment of rabies in dogs. The utilization of relatively few medicinal plants for treatment of poultry, equines and dogs might be associated to the low perception, low occurrence of diseases affecting and low ethnoveterinary experiences of herbalists on these species. In the same way, the highest percentage of medicinal plants used to treat infectious diseases in the study area could also be related to high occurrence of such diseases in Dawuro zone. This was justified by presence of highest number of infectious diseases (accounting $63.4 \%$ of livestock ailments in the area) reported by informants. Furthermore, this study also revealed that traditional veterinary practices in the area are well focused to the most prevailing health problems.

The method of treatment preparation in many cases varied from individual to individual. The same plant materials for the same ailment are prepared in different ways by different traditional veterinary healers. Thus, traditional remedy preparation was also varied in plant species compositions. In this study, traditional healers prepare ethnoveterinary recipes mostly in the forms of pounding and homogenizing with water followed by crushing. This finding is in agreement with $[31,57,65,66]$ who reported pounding the remedial part and homogenizing it with water was found to be the major mode of remedy preparation.

Most of the recipes are prepared using single plant (93.4\%) while some of the recipes are also prepared in the form of mixed two or more plants together (6.6\%). Thus, the widely using of single plant species for the preparation of local medicines in the study area is in agreement with the finding of [67, 68, 69]. However, it is generally believed that potency of the treatments can be enhanced when used in concoction form described by [26].

Results of present study also showed that some plants are used to treat more than one disease, while others are used manage one ailment. The highest number of multiple ethnoveterinary uses was recorded for Capsicum frutescens (treated against 12 ailment types) and Lepidium sativum (10 ailment types each). Herbalists in the same geographical area often cite different herbal treatments for the same disease, and variations were often encountered in the method of preparation, dosing, and routes of administration. This finding is inconsistent with other ethnoveterinary studies conducted in Ethiopia and elsewhere $[17,31]$ who reported that Allium sativum and $C$. guianensis were highest number of multiple ethnoveterinary uses, respectively.

The present study showed that the claimed medicinal plants have values other than their medicinal roles. They are used by the community for different purposes such as, human disease treatment, fire wood, construction, timber production, animals' fodder, fence, edible, spices, and other uses such as agricultural tools and soil conservation. This finding is similar to other studies from different parts of Ethiopia [41, 57, 70].

The results also revealed that few traditional herbalists (7\%) preferred days and time for plant collection like on Sunday and Wednesday and at early morning without contact with any person 00000which they believe that will make the treatment more efficacies to cure diseases. Nearly similar findings were reported from Ejaji area (Chelya Woreda) in West Shoa [57] and Gimbi area, in Western Wellega [58] who pointed out medicinal plant collection and provision was restricted to and done on Sunday, Wednesday and Friday. However, the majority of traditional healers reported that there is no taboos association (93\%) with medicinal plant collection and uses in the study area. This result is in line with the finding from other parts of Ethiopia [38].

\section{Market Survey of Ethnoveterinary Plants}

Marketing of medicinal plants are not common practices at the studied area. Local community mainly harvest and use ethnoveterinary plants for a private use with their own livestock. However, a limited range of buying and selling medicinal plant was practiced at Tocha, Waka, Wara, Gassa c'are and Orobi local markets in the Districts. About18 species of medicinal plants in veterinary use were showed to be accessible on the market and only 3 species i.e., Lannea fruticosa (Dechimarac'iya) and Echinops kebericho (Burssa) (0.34 US Dollar about 200-250 gm dried root material), and Pentas schimperiana (Dawuridama) (0.142 US Dollar) about 250-500 gm bunch of leaf material) seem to be purchased solely for use in traditional medical applications. The remaining 15 marketed species were mainly sold for their uses other than medicine i.e., food, spices and other purposes though they were mentioned to be occasionally used as remedies when there is a need. This was also reported in other ethnoveterinary survey [31, 71]. A few traditional healers treat sick animals sometimes free of charge if close relations exist. However, a majority of them believed that whatever relation existed, the owner had to pay money for the plants; otherwise they underlined that the medicine would not be effective.

\section{Informant Consensus Factor, Fidelity Level, Preference Ranking and Use-value of Ethnoveterinary Plants}

The observed highest informants' consensus (ICF=0.83) on ethnoveterinary medicinal plants used to treat diseases of reproductive system followed by infectious (ICF=0.78) in the area. The findings of [26] from Pakistan and Ethiopia [66] have indicated that the highest share of similar plant use information within a community for disease of reproductive system and infectious category, respectively, while disagrees with other studies in Ethiopia [31] who reported high ICF in the gastrointestinal disease category. The recorded high plant use citation for treating ailments in the infectious disease category might also indicate the relatively high occurrence of such diseases and ease of identifying ailments and corresponding curative plants occurring in the Zone.

Highest fidelity level values were obtained for Cyphostema sp. in the diseases of reproductive system, Calpurina aurea in the ectoparasites, and Pentas schimperiana in the fattening and bone broken disease category accounts (100\% each) followed by Eucalphytus globules ( $91.67 \%)$ in the infectious/blackleg disease category and Croton macrostachyus (90.9\%) for the wound and trauma therapeutic category indicates relatively high healing potential of the species

Page $11 / 23$ 
for treating ailments under the respective categories. The highest FL might be related to which the cited plants species has more healing power contributed to the presence of bioactive compounds for the respective ailments. Analysis of the preference ranking exercise also indicated that Azadirachta indica and Eucalphytus globules were the most preferred ethnoveterinary medicinal plants used to treat blackleg, the most commonly reported disease in the study area. This may be attributed to the presence of bioactive compounds against causative agents of blackleg in these species.

According to [17] the use value is a quantitative method that demonstrates the relative importance of species known locally. This method can be used to select species for cultivation in gardens or construction of medical work of scientific validation. Results of this study showed that Azadirachta indica and Eucalphytus globules were the species with highest use-value, probably because they are dominant vegetation and high curative activity one, they trust in the study area. This result is disagreement with other ethnoveterinary studies $[17,36]$ who reported that Carapa guianensis Aubl. and Cedrelopsis grevei were species with highest use-value, respectively. Medicinal plant species cited by more than two informants are considered as the most used medicinal plants are found by [36]. In this study, all the identified medicinal plants are cited by two and more than two informants.

\section{Threats to and Conservation of Medicinal Plants}

Although the value of indigenous knowledge in livestock disease treatment is indispensable; the local communities and government did not give due attention for conservation of traditional medicinal plants. There are different threats to medicinal plant availability and indigenous knowledge in the study area. In this study, indigenous knowledge on ethnoveterinary medicinal plants are becoming scarcer due to different threats such as agricultural expansion, unselective harvesting, overgrazing, uncontrolled bushfires, drought, deforestation, landslide, pesticide spraying, and population increase. These findings are in accordance with the reports of $[10,30,41,72]$ who noted that the major threats for medicinal plants in the different parts of Ethiopia. Among the major threats, drought is the most threating factor to medicinal plants, which is in line with finding of [72] who reported that responses of lowland agro-ecology stated that prolonged dry season is the most pressing factor followed by agricultural expansion.

The study found that there is no any support and encouragement from governmental and non-governmental organizations in conservation and sustainable utilization of medicinal plants. In addition, most of the traditional practitioners have no clear awareness on the conservation of plants with medicinal value. However, someone have home garden and on agricultural field management practices of medicinal plants conservation was practiced. It is once a year that some medicinal plants like Lepidium sativum, Maerue oblongifolia, Lannea fruticosa, Nicotiana tabacum, Piper capense, Embelia schimperi, and Echinops kebericho seed, leaf, fruit or root, respectively are harvested, dried and preserved in roof corners or outside house, and dried parts are stored in special place for further use.

\section{Non-plant Treatments and Factors Contributing to Use of Ethnoveterinary Medicine in the Study Area}

There is abundant undocumented traditional knowledge of non-medicinal plant materials used to treat various livestock diseases on study area have had a significant effect on animal health practices. The survey also revealed that eleven (11) non-plant remedies are used by the herbalists in the study area. Some of the non-plant medicinal materials reported include hyena faece, wood ash, honeydew, oils, kerosene, local soap, salt, porcupine meat, dear faece, sharp hot iron or knife, milk, fermented kocho (Ensete ventricosum), porridge and the end product of Ensete ventricosum fluid traditionally called "Zaalima" which they believed were effective in ethnoveterinary management. Nearly similar ethnoveterinary studies conducted in Nigeria [27] share a similar concern on the knowledge of non-medicinal plant ethnoveterinary practices found that sharp hot iron or branding for treatment of blackleg and inflammation due to trauma, salt used for appetite promotion, and vegetable oil for managing bloat, respectively. However, hynae feaces, wood ash, dear faeces, porcupine meat, fermented kocho (C'aalaa unc'c'a), the end product of local kocho fluid (Zaalima), and honeydew has not been reported before other ethnoveterinary survey of non-plant remedies used in Ethiopia.

According to [73] the use of animals for medicinal purposes is part of a body of traditional knowledge which is increasingly becoming more relevant to discussions on conservation biology, public health policies, and sustainable management of natural resources, biological prospection and patents. In this perspective, the present study was also undertaken to document information about local animals used in veterinary medications by traditional herbalists in the Dawuro zone. According to informants, the products and parts of porcupine, hyena, cattle, bear and aphids (insects) were used by the community in ethnoveterinary practices. Other studies have likewise highlighted these medicinal animals used in ethnoveterinary practices from other parts of the world [73, $74,75]$.

The factors contributing for medicinal plants and non-plants of use as ethnoveterinary treatments, are easy accessibility, inadequate number of formal veterinary clinics and veterinarians, primary healthcare system, apparent effectiveness, lack of adequate modern drugs, long distance to veterinary clinic station, affordability and low cost, and some diseases did not respond to modern drugs available in the area that would never be enough to provide healthcare services for more than $3,543,417$ livestock population. Moreover, almost all of the rural community lives in marginal areas which are not easily accessible to the rare modern veterinary services which are also known for their scorching prices totally unaffordable to the less economically endowed people living there. This finding is similar with the work of [7, 31] in the Ethiopia, in South Africa [43] and in Brazil [73].

\section{Conclusion}


The present study revealed that the study area has plenty of ethnoveterinary medicinal plants to treat a wide range of livestock health problems. The average informant consensus factor of $(0.614)$ is high indicating that different treatments are cited for different ailments and the degree of agreement was high. The documented indigenous knowledge of medicinal plants and non-plant materials are valuable for the communities and their next generations and has the potential sources for the discovery of new drugs to manage the diseases of animals. However, individuals who are knowledgeable in ethnoveterinary practices were passes away and high secrecy, drought, overgrazing, population increase, unselective harvesting and intense deforestation increased need for farmlands and bush fire in the study area were the major natural and manmade threats affecting medicinal plant resources and indigenous knowledge. Moreover, documentation and conservation of more ethnoveterinary medicinal plants and non-plant materials, and associated indigenous knowledge in study area is very crucial. Knowledge of ethnoveterinary practitioners have to be encouraged and protected from the wrong perception, strong government policy support, creating awareness and training to the herbalists in particular and local community in general to grow medicinal plants which promote sustainable utilization, conservation and application. Progressive efforts are vital to integrate modern veterinary healthcare with ethnoveterinary medicine. Further researches need to be conducted to validate the biological ingredients and test the safety, efficacy, and toxicity since herbal preparations are crude.

\section{Declarations}

\section{Ethics approval and consent to participate}

Prior to conducting the study, verbal consent was obtained from all participants. No additional ethics approval was required.

\section{Consent for publication}

This manuscript does not contain any individual person's data and further consent for publication is not vital.

\section{Availability of data and materials}

The raw data contain the list of all informants name, and cannot be public in this form.

\section{Competing interests}

The author declare that they have no conflict of interests

\section{Funding}

Not applicable

\section{Author's contributions}

TD performed field data collection, carried out the main survey work and prepared first draft of the paper. FB, and TT were separately providing constructive comments to develop final draft of the paper. All authors involved, read and approved the final manuscript.

\section{Author's details}

${ }^{1}$ Ambo University College of Agriculture and Veterinary Science, P.O. Box, 19, Guder Campus, Ambo, Ethiopia, E-mail: dilbatot@gmail.com. ${ }^{2}$ Jimma University, College of Agriculture and Veterinary Medicine, School of Veterinary Medicine, P.O. Box 378, Jimma, Ethiopia.

\section{Acknowledgements}

We would like to thank the local communities and informants of Dawuro Zone for their support and for sharing their invaluable knowledge on ethnoveterinary practices during data collection. We would also like to thank Mr. Ambaye Tadesse and Development Assistants (DA's) of the study districts for their cooperation.

\section{References}

1. Wanzala W. Ethnoveterinary medicine: a critical review of its evolution, perception, understanding and the way forward. Livestock Research for Rural Development, 2005. https://www.researchgate.net/publication/288359282.

2. Sori T, Bekana M, Adugna G, Kelbessa E. Medicinal plants in the ethnoveterinary practices of Borana pastoralists, Southern Ethiopia. Int J Appl Res Vet Med. 2004;2(3):220-5.

3. Wondimu T, Asfaw Z, Kelbessa E. Ethnobotanical study of medicinal plants around 'Dheeraa'town, Arsi Zone, Ethiopia. Journal of Ethnopharmacology. 2007 May 30;112(1):152-61.

4. Teshager A, Belay D, Taye T. Prevalence of cattle diseases and productive and reproductive traits of cattle in llu Aba Bora zone, south western Ethiopia. Global Veterinaria. 2013;10(5):614-9.

5. Fullas F. Ethiopian medicinal plants in veterinary healthcare. A mini-review. Ethiopian e-journal for research innovation foresight. 2010;2(1):48-58.

6. Melaku A, Kebede H, Kebede E. Constraints in animal health service delivery and sustainable improvement alternatives in North Gondar, Ethiopia. Onderstepoort J Vet Res. 2014;81:1.

7. Wabe N, Mohammed MA, Raju NJ. An ethnobotanical survey of medicinal plants in the Southeast Ethiopia used in traditional medicine. Spatula DD. 2011;1(3):153-8. 
8. Kalayou S, Haileselassie M, Gebre-egziabher G, Tiku'e T, Sahle S, Taddele H, Ghezu M. In-vitro antimicrobial activity screening of some ethnoveterinary medicinal plants traditionally used against mastitis, wound and gastrointestinal tract complication in Tigray Region, Ethiopia. Asian Pac J Trop Biomed. 2012;2(7):516-22.

9. Edwards S, Tadesse M, Demissew S, Hedberg I, editors. Flora of Ethiopia and Eritrea. Magnoliaceae to Flacourtiaceae. Volume 2. Issue part 1. Uppsala: The National Herbarium, Addis Ababa, Ethiopia, and Department of Systematic Botany; 2000.

10. Yirga G, Teferi M, Gidey G, Zerabruk S. An ethnoveterinary survey of medicinal plants used to treat livestock diseases in Seharti-Samre district, Northern Ethiopia. Afr. J. Plant Sci. 2012 Feb 6;6(3):113-9.

11. Mengistu A. The Effect of Herbal Preparations on Staphylococcus aureus and Streptococcus agalactiae Isolated from Clinical Bovine Masstitis (Doctoral dissertation, Addis Ababa University); 2004. http://213.55.95.56/handle/123456789/4062.

12. Giday M, Ameni G. An ethnobotanical survey of plants of veterinary importance in two woredas of Southern Tigray, Northern Ethiopia. SINET: Ethiop J Sci.; 2005; 26:2.

13. Gebrezgabiher G, Kalayou S, Sahle S. An ethnoveterinary survey of medicinal plants in woredas of Tigray region, Northern Ethiopia. Int J Biodivers Conserv. 2013;5:89-97.

14. Kibebew F. The status and availability of oral and written knowledge on traditional health care on traditional health care in Ethiopia. In Conservation and sustainable use of medicinal plants in Ethiopia, Proceedings of the National workshop, 28 April-01 May 1998 2001 Apr (pp. 107-119).

15. Alexiades MN. Collecting ethnobotanical data. An introduction to basic concepts and techniques. In Selected Guideline for Ethnobotanical Research: A Field Manual. Edited by Alexiades MN, Sheldon JW. Bronx, New York: The New York Botanical Garden; 1996; 53-94.

16. McCorkle CM. Back to the future: Lessons from ethnoveterinary RD and E for studying and applying local knowledge. Agri Human Value. 1995;12(2):5280.

17. Monteiro MVB, Bevilaqua CML, Palha MDDC, Braga RR, Schwanke K, Rodrigues ST, Lameira OA. Ethnoveterinary knowledge of the inhabitants of Marajó Island, Eastern Amazonia, Brazil. Acta Amaz. 2011;41(2):233-42.

18. Bekele D, Asfaw Z, Petros B, Tekie H. Ethnobotanical study of plants used for protection against insect bite and for the treatment of livestock health problems in rural areas of Akaki District, Eastern Shewa, Ethiopia. Topclass Journal of Herbal Medicine. 2012;1(2):12-24.

19. Kefalew A. Transference of Ethnobotanical Knowledge and Threat \& Conservation Status of Medicinal Plants in Ethiopia: Anthropological and Ethnobotanical Perspectives. Archaeology \& Anthropology; 2017.

20. Dawuro Zone Finance and Economic Development Department. The Socio-Economic Profile of Dawuro Zone. Dawuro: Annual Statistical Abstract; 2017.

21. Abebe A, Tesfaye Z. Defensive Walls under Threat: Examining the Status of the Great Medieval Defensive Walls of Dawuro People in Southern Ethiopia; 2015. http://internationaljournalofresearch.org/index.php/JSMaP.

22. Dawuro Zone Livestock and Fisheries Development Department. Livestock Population Data. Tarcha: Dawuro; 2017.

23. Martin GJ. Ethnobotany, conservation and community development. Springer US; 1995;223-51.

24. Cotton CM. Ethnobotany: principles and applications. Chichester: John Wiley \& Sons; 1996.

25. Hoffman B, Gallaher T. Importance indices in Ethnobotany. Ethnobotany Research Applications. 2007;5:201-18.

26. Tariq A, Mussarat S, Adnan M, AbdElsalam NM, Ullah R, Khan AL. Ethnoveterinary study of medicinal plants in a tribal society of Sulaiman range. Sci World J. 2014: 1-10.

27. Alhaji NB, Babalobi OO. Participatory epidemiology of ethnoveterinary practices Fulani pastoralists used to manage contagious bovine pleuropneumonia and other cattle ailments in Niger State, Nigeria. J Vet Med, 2015: 10.

28. Phillips O, Gentry AH. The useful plants of Tambopata, Peru: I. Statistical hypotheses tests with a new quantitative technique. Econ Bot. 1993;47(1):1532.

29. Drug Administration and Control Authority of Ethiopia. Standard Veterinary Treatment Guidelines for Veterinary Clinics, First Ed. DACA; 2006.

30. Giday M, Asfaw Z, Woldu Z. Medicinal plants of the Meinit ethnic group of Ethiopia: an ethnobotanical study. J Ethnopharmacol. 2009;124(3):513-21.

31. Lulekal E, Asfaw Z, Kelbessa E, Van Damme P. Ethnoveterinary plants of Ankober District, North Shewa Zone, Amhara Region, Ethiopia. J Ethnobiol Ethnomed. 2014;10(1):21.

32. Teklehaymanot T. An ethnobotanical survey of medicinal and edible plants of Yalo Woreda in Afar regional state, Ethiopia. J Ethnobiol Ethnomed. 2017;13(1):40.

33. Begossi A, Hanazaki N, Tamashiro JY. Medicinal plants in the Atlantic Forest (Brazil): Knowledge, use, and conservation. Human Ecology. 2002;30(3):281-99.

34. Teklehaymanot T. Ethnobotanical study of knowledge and medicinal plants use by the people in Dek Island in Ethiopia. J Ethnopharmacol. 2009;124(1):69-78.

35. Seifu T, Asres K, Gebre-Mariam T. Ethnobotanical and ethnopharmaceutical studies on medicinal plants of Chifra district, Afar region. North Eastern Ethiopia Ethiop Pharma J. 2006;24(1):41-58.

36. Randrianarivony TN, Ramarosandratana AV, Andriamihajarivo TH, Rakotoarivony F, Jeannoda VH, Randrianasolo A, Bussmann RW. The most used medicinal plants by communities in Mahaboboka, Amboronabo, Mikoboka, South-western Madagascar. J Ethnobiol Ethnomed. 2017;13(1):19.

37. Lulekal E, Kelbessa E, Bekele T, Yineger H. An ethnobotanical study of medicinal plants in Mana Angetu District, Southeastern Ethiopia. J Ethnobiol Ethnomed. 2008;4(1):10. 
38. Yineger $\mathrm{H}$, Yewhalaw D, Teketay D. Ethnomedicinal plant knowledge and practice of the Oromo ethnic group in southwestern Ethiopia. J Ethnobiol Ethnomed. 2008;4(1):11.

39. Uniyal SK, Singh KN, Jamwal P, Lal B. Traditional use of medicinal plants among the tribal communities of Chhota Bhangal, Western Himalaya. J Ethnobiol Ethnomed. 2006;2(1):14.

40. Silva FDS, Ramos MA, Hanazaki N, Albuquerque UPD. Dynamics of traditional knowledge of medicinal plants in a rural community in the Brazilian semiarid region. Rev Bras Farmacogn. 2011;21(3):382-91.

41. Tekle Y. An ethnoveterinary botanical survey of medicinal plants in Kochore district of Gedeo Zone, Southern Nations Nationalities and Peoples Regional State (SNNPRs), Ethiopia. Journal of Science Innovative Research. 2014;3(4):433-45.

42. Yigezu Y, Haile DB, Ayen WY. Ethnoveterinary medicines in four districts of Jimma zone, Ethiopia: cross sectional survey for plant species and mode of use. BMC Vet Res. 2014;10(1):76.

43. Soyelu OT, Masika PJ. Traditional remedies used for the treatment of cattle wounds and myiasis in Amatola Basin, Eastern Cape Province, South Africa. Onderstepoort J Vet Res. 2009;76(4):393-7.

44. Luseba D, Tshisikhawe MP. Medicinal plants used in the treatment of livestock diseases in Vhembe region, Limpopo province, South Africa. Journal of Medicinal Plant Research. 2013;7(10):593-601.

45. Zia-ud-Din S, Zafar I, Khan MN, Jonsson NN, Muhammad S. Documentation of ethnoveterinary practices used for treatment of different ailments in a selected hilly area of Pakistan. International Journal of Agriculture Biology. 2010;12(3):353-8.

46. Dey A, De JN. Ethnoveterinary uses of medicinal plants by the aboriginals of Purulia district, West Bengal, India. I J Bot. 2010;6(4):433-40.

47. Panda SS, Dhal NK. Plants used in ethno-veterinary medicine by native people of Nawarangpur district, Odisha, India. World Journal of Pharmacy Pharmaceutical Science. 2014;3:787-98.

48. Offiah NV, Makama S, Elisha IL, Makoshi MS, Gotep JG, Dawurung CJ, Oladipo 00, Lohlum AS, Shamaki D. Ethnobotanical survey of medicinal plants used in the treatment of animal diarrhea in Plateau State, Nigeria. BMC Vet Res. 2011;7(1):36.

49. Hunde D, Asfaw Z, Kelbessa E. Use of traditional medicinal plants by people of 'Boosat'sub district, Central Eastern Ethiopia. Ethiop J Health Sci. 2006;16:141-55.

50. Bekalo TH, Woodmatas SD, Woldemariam ZA. An ethnobotanical study of medicinal plants used by local people in the lowlands of Konta Special Woreda, Southern Nations, Nationalities and Peoples Regional State, Ethiopia. J Ethnobiol Ethnomed. 2009;5(1):26.

51. Mesfin F, Demissew S, Teklehaymanot T. An ethnobotanical study of medicinal plants in Wonago Woreda, SNNPR, Ethiopia. J Ethnobiol Ethnomed. 2009;5(1):28.

52. Agize M, Demissew S, Asfaw Z. Ethnobotany of medicinal plants in Loma and Gena bosa districts (woredas) of Dawro zone, southern Ethiopia. Topclass Journal of Herbal Medicine. 2013;2(9):194-212.

53. Zenebe G, Zerihun M, Solomon Z. An ethnobotanical study of medicinal plants in Asgede Tsimbila district, Northwestern Tigray, northern Ethiopia. Ethnobotany Research Applications. 2012;10:305-20.

54. Birhanu T, Abera D. Survey of ethnoveterinary medicinal plants at selected Horro Gudurru Districts, Western Ethiopia. Afr J Plant Sci. 2015;9(3):185-92.

55. Farooq Z, Iqbal Z, Mushtaq S, Muhammad G, Iqbal MZ, Arshad M. Ethnoveterinary practices for the treatment of parasitic diseases in livestock in Cholistan desert (Pakistan). J Ethnopharmacol. 2008;118(2):213-9.

56. Hunde D, Asfaw Z, Kelbessa E. Use and management of ethnoveterinary medicinal plants by indigenous people of' Boosat', Welenchita area. Ethiop J Biol Sci. 2004;3(2):113-32.

57. Amenu E. Use and Management of Medicinal Plants by Indigenous People of Ejaji Area (Chelya Woreda) West Shoa, Ethiopia: An Ethnobotanical. 2007. http://etd.aau.edu.et/handle/123456789/4095.

58. Tolasa E. Use and Conservation of Traditional Medicinal Plants by Indigenous People in Gimbi Woreda, Western Wellega, Ethiopia; 2007. http://etd.aau.edu.et/handle/123456789/4270. 59. Yineger H, Yewhalaw D. Traditional medicinal plant knowledge and use by local healers in Sekoru District, Jimma Zone, Southwestern Ethiopia. J Ethnobiol Ethnomed. 2007; 3:24.

59. Ugulu I. Fidelity level and knowledge of medicinal plants used to make therapeutic Turkish baths. Studies on Ethnomedicine. 2012;6(1):1-9.

60. Aloto D, Eticha E. Leeches. A Review on their Pathogenic and Beneficial Effects. J Vet Sci Techno. 2018;9(1):511.

61. Kebede A, Ayalew S, Mesfin A, Mulualem G. Assessment on the Use, Knowledge and Conservation of Medicinal Plants in Selected Kebeles of Dire Dawa Administration, Eastern Ethiopia. J Plant Sci. 2017;5(2):56-64.

62. Hussain A, Khan MN, Iqbal Z, Sajid MS. An account of the botanical antihelminthics used in traditional veterinary practices in Sahiwal district of Punjab, Pakistan. J Ethnopharmacol. 2008;119(1):185-90.

63. Suleman S, Alemu T. A survey on utilization of ethnomedicinal plants in Nekemte town, East Wellega (Oromia), Ethiopia. J Her Spic Med plant. 2012;18(1):34-57.

64. Eshetu GR, Dejene TA, Telila LB, Bekele DF. Ethnoveterinary medicinal plants: Preparation and application methods by traditional healers in selected districts of Southern Ethiopia. Vet World. 2015;8(5):674.

65. Alemayehu G. Ethnobotanical Study on Medicinal Plants Used by Indigenous Local Communities in Minjar-Shenkora Wereda, North Shewa Zone of Amhara Region, Ethiopia; 2010. http://etd.aau.edu.et/handle/123456789/5145.

66. Tamene B. A floristic analysis and ethnobotanical study of the semi-wet land of Cheffa area, South Wello, Ethiopia (Doctoral dissertation, Sc M. Thesis); 2000. http://etd.aau.edu.et/handle/123456789/2934.

Page 15/23 
67. Balemie K, Kelbessa E, Asfaw Z. Indigenous medicinal plant utilization, management and threats in Fentalle area, Eastern Shewa, Ethiopia. Ethiop J Biol Sci. 2004;3:37-58.

68. Giday M, Teklehaymanot T, Animut A, Mekonnen Y. Medicinal plants of the Shinasha, Agew-awi and Amhara peoples in northwest Ethiopia. J Ethnopharmacol. 2007;110(3):516-25.

69. Kebebew M, Mohamed E. Indigenous knowledge on use of medicinal plants by indigenous people of Lemo district, Hadiya zone, Southern Ethiopia. I J Herb Med. 2017;5:124-35.

70. Mander M, Emana B, Asfaw Z, Busa B. Marketing of medicinal plants in Ethiopia. A survey of the Trade in Medicinal Plants: A research report prepared by Sustainable Use of Medicinal Plants Project. Addis Ababa, Ethiopia; IBC; 2006.

71. Teklay A, Abera B, Giday M. An ethnobotanical study of medicinal plants used in Kilte Awulaelo District, Tigray Region of Ethiopia. J Ethnobiol Ethnomed. 2013;9(1):65.

72. Souto WM, Mourão JS, Barboza RR, Mendonça LE, Lucena RF, Confessor MV, Vieira WL, Montenegro PF, Lopez LC, Alves RR. Medicinal animals used in ethnoveterinary practices of the 'Cariri Paraibano', NE Brazil. J Ethnobiol Ethnomed. 2011;7(1):30.

73. Padmanabhan P, Sujana KA. Animal products in traditional medicine from Attappady hills of Western Ghats. Indian Journal of Traditional Knowledge. 2008;7(2):326-9.

74. Vats R, Thomas S. A study on use of animals as traditional medicine by Sukuma Tribe of Busega District in North-western Tanzania. J Ethnobiol Ethnomed. 2015;11(1):38.

\section{Tables}

Table 2 List of ethnoveterinary medicinal plants used for treatment of livestock ailments: scientific name, family name, local name, plant type, veterinary uses; parts used; methods of preparation, route of administration, and use-value. 


\begin{tabular}{|c|c|c|c|c|c|c|}
\hline Scientific name & Family name & Local name & Part & Type & Preparation & Route \\
\hline Clerodendrum myricoides & Lamiaceae & Algaa & $L, R$ & S & $\begin{array}{l}\text { Pounding and mix with } \\
\text { salt }\end{array}$ & 0 \\
\hline Croton macrostachyus & Euphorbiaceae & Ankaa & $R, L$ & $\operatorname{Tr}$ & $\begin{array}{l}\text { Dried and powdering, } \\
\text { direct apply }\end{array}$ & $\mathrm{Tp}, 0$ \\
\hline Artemisia annua $L$. & Asteraceae & Ars'imiiziya & $\mathrm{L}$ & $\mathrm{H}$ & $\begin{array}{l}\text { Pounding and } \\
\text { homogenizing with } \\
\text { water }\end{array}$ & 0 \\
\hline Jatropha curcas & Euphorbiaceae & Atiya & L & S & $\begin{array}{l}\text { Pound and homogenize } \\
\text { with water and } \\
\text { thoroughly strained }\end{array}$ & 0 \\
\hline Abrus precatoris & Fabaceae & Badalluwa & $\mathrm{Sd}$ & $\mathrm{Cl}$ & Roasted, powdered & 0 \\
\hline Cyperus articulata & Cyraceae & Bidaaraa & $\mathrm{R}$ & $\mathrm{H}$ & Pounding & 0 \\
\hline Erthrina abyssinica & Fabaceae & Bortuwa & $\mathrm{B}$ & $\operatorname{Tr}$ & Pounding & O, Tp \\
\hline Eriosema sp. & Fabaceae & Boshuwa & $\mathrm{R}$ & $\mathrm{Cl}$ & $\begin{array}{l}\text { Chopped, pound, as } \\
\text { bedding material }\end{array}$ & 0 \\
\hline Eucalphytus globules & Myrtaceae & Bootsa Baaliazaafiya & $L, S$ & $\operatorname{Tr}$ & Pounding & $\mathrm{O}, \mathrm{N}$ \\
\hline Echinops kebericho & Asteraceae & Bursaa & $\mathrm{R}$ & $\mathrm{H}$ & $\begin{array}{l}\text { Put together with Hagnia } \\
\text { abyssinica on the fire, } \\
\text { pounding }\end{array}$ & Fum/sk, 1 \\
\hline Premna schimperiana & Lamiaceae & C'aawula & $L, S$ & $\operatorname{Tr}$ & Ground & 0 \\
\hline Clutia abyssinica & Euphorbiaceae & C'ac'c'awuwa & L & S & Pounding & 0 \\
\hline $\begin{array}{l}\text { Clausena anisata (Willd.) } \\
\text { Benth. }\end{array}$ & Rutaceae & C'iik'otiya/s'alk'imaallo & L & S & Pounding & 0 \\
\hline Conyza pyrrhopapa & Asteraceae & D'oniya & L & $\mathrm{H}$ & Pounding & 0 \\
\hline Clutia abyssinica Jaub.\&Spach & Euphorbiaceae & Dada shooliya & $\mathrm{Br}$ & S & Pounding & 0 \\
\hline $\begin{array}{l}\text { Schefflera abyssinica (Hochst. } \\
\text { ex A. Rich.) Harms }\end{array}$ & Araliaceae & Darguwa & $\mathrm{Br}$ & $\operatorname{Tr}$ & Pounding & O, Tp \\
\hline Lannea fruticosa & Annacardiaceae & Dechimarac'c'iya & $\mathrm{R}$ & $\operatorname{Tr}$ & Pounding & $\mathrm{O}, \mathrm{N}$ \\
\hline Plectranthus ornatus & Lamiaceae & Dissaa & $L, R$ & $\mathrm{H}$ & Pounding & 0 \\
\hline $\begin{array}{l}\text { Solanecio mannii } \\
\text { (Hookf)C.Jeffery }\end{array}$ & Asteraceae & Don'arkiya & $\mathrm{R}$ & s & $\begin{array}{l}\text { Wash slightly and } \\
\text { Pounding }\end{array}$ & 0 \\
\hline Cyanthula cylindrical & Amaranthaceae & $\begin{array}{l}\text { Dorsa } \\
\text { k'archochcha/gumpullaa }\end{array}$ & $\mathrm{R}$ & $\mathrm{H}$ & Pounding & 0 \\
\hline $\begin{array}{l}\text { Rhoicissus tridentata (L. f) } \\
\text { Wild \& Drummond }\end{array}$ & Vitaceae & Illallaa & $\mathrm{L}$ & $\operatorname{Tr}$ & Pounding fresh leaf & 0 \\
\hline Fiscas vastas & Moraceae & Esaa/Ettaa & $\mathrm{Br}$ & $\operatorname{Tr}$ & Pounding & 0 \\
\hline Carduus chamaecephalus & Asteraceae & Gezziya kashiya & $\mathrm{R}$ & $\mathrm{H}$ & Pounding & $\mathrm{O}, \mathrm{N}$ \\
\hline
\end{tabular}

Page 17/23 


\begin{tabular}{|c|c|c|c|c|c|c|}
\hline Amaranthas caudatus $L$. & Amaranthaceae & Gaggabaa & $\mathrm{Sd}$ & $\mathrm{H}$ & Roast and ground & 0 \\
\hline Vernonia amygidalina & Asteraceae & Garaa & L & $\operatorname{Tr}$ & $\begin{array}{l}\text { Pounding and mix with } \\
\text { salt }\end{array}$ & O, Tp \\
\hline Acacia sp. & Fabaceae & Garigaaruwa & L & $\operatorname{Tr}$ & Pounding & O, sprayir \\
\hline Dracaena steudneri Engler & Dracaenacae & Geggeluwa & $\mathrm{R}$ & $\mathrm{Cl}$ & $\begin{array}{l}\text { Chopped, dried, } \\
\text { powdering and mix with } \\
\text { barely, Lepidium sativum } \\
\text { and salt }\end{array}$ & 0 \\
\hline Aloe otallensis Baker & Alloaceae & Godare uutsaa & L & $\mathrm{H}$ & $\begin{array}{l}\text { Fresh leaf exudates, } \\
\text { pounding, squeezing }\end{array}$ & Tp, N \\
\hline Chenopodium murale L. & Chenopodiaceae & Goono Sibikkaa & $\mathrm{Sd}$ & $\mathrm{H}$ & Pounding & 0 \\
\hline Phytolacca dodcandra & Phytolacaceae & Hanc'c'ic'aa & $\begin{array}{l}\text { Sd, L, } \\
\mathrm{R}\end{array}$ & $S$ & $\begin{array}{l}\text { Pounding, ground only } 2 \\
\text { cup }\end{array}$ & $\mathrm{N}$ \\
\hline $\begin{array}{l}\text { Cyphostemma adenocaule } \\
\text { (Steud. ex A. Rich.) Desc. ex } \\
\text { Wild \& Drummond }\end{array}$ & Vitaceae & Higishshaa d’aliya/Turaa & $\mathrm{R}$ & $\mathrm{Cl}$ & Wash and pound & 0 \\
\hline Cyphostema sp. & Vitaceae & Higishsha d'aliya/Ba"o & $\mathrm{R}$ & $\mathrm{H}$ & $\begin{array}{l}\text { Pounding and mix with } \\
\text { milk }\end{array}$ & $\mathrm{N}, \mathrm{Ar}$ \\
\hline Eubolia schimperi & Poaceae & K'ank'k'uwa & Sd, L & $S$ & Grinding & $\mathrm{N}$ \\
\hline Momordica foetida schumach & Cucurbitaceae & K'ec'aa & L & $\mathrm{Cl}$ & Pounding & O, Tp \\
\hline Piper nigrum & Piperaceae & K'unddobambbariyaa & L & $\operatorname{Tr}$ & Pounding & 0 \\
\hline Buddleja polystachya & Luganiaceae & Kanfaaraa & L & $\operatorname{Tr}$ & $\begin{array}{l}\text { Pounding together with } \\
\text { Piper capense, } \\
\text { Eucalphytus globules, } \\
\text { Justica schimperiana } \\
\text { and mixed with water }\end{array}$ & 0 \\
\hline Echinops amplexcaulis & Asteraceae & Gad'aa kashiya/Wora burssa & $\mathrm{R}$ & S & Pounding & 0 \\
\hline $\begin{array}{l}\text { Sida schimperiana Hochst. ex } \\
\text { A. Rich. }\end{array}$ & Malvaceae & Kindichchuwa & $\begin{array}{l}\mathrm{R}, \mathrm{L} \\
\mathrm{Sm}\end{array}$ & $S$ & $\begin{array}{l}\text { Pounding, mixed with } \\
\text { milk for dogs }\end{array}$ & 0 \\
\hline Tragia sp. & Euphorbiaceae & Kinkilishuwa & $\mathrm{R}, \mathrm{L}$ & $\mathrm{Cl}$ & $\begin{array}{l}\text { Pounding and mix with } \\
\text { water }\end{array}$ & $\mathrm{O}, \mathrm{N}$ \\
\hline Ageratum conyzoides $L$. & Asteraceae & Kirkissaa/Puk'ak'iya & L & $\mathrm{H}$ & Pounding & 0 \\
\hline Carrisa spinarum & Apocyanaceae & Laadiya & $\mathrm{R}$ & $S$ & Pounding & O, Aur \\
\hline Datura stramonium & Solanaceae & Lafilafuwa & $\mathrm{L}, \mathrm{Sm}$ & $\mathrm{H}$ & Pounding & 0 \\
\hline Cucurbita pepo L. & Cucurbitaceae & Leekiya & $\mathrm{Sd}$ & $\mathrm{H}$ & Ground & 0 \\
\hline Citrus aurantifolia & Rutaceae & Loomiya & $\mathrm{Fr}$ & $\operatorname{Tr}$ & $\begin{array}{l}\text { Chopped, squeezing the } \\
\text { juice }\end{array}$ & 0 \\
\hline $\begin{array}{l}\text { Arisaema enneaphyllum } \\
\text { Hochst.exA. Rich }\end{array}$ & Araceae & $\begin{array}{l}\text { Mahe } \\
\text { mak'k'a/K'ols's'uwa/Babark'ee } \\
\text { badalaa }\end{array}$ & $L, R$ & $\mathrm{H}$ & Pounding & $\mathrm{O}, \mathrm{N}$ \\
\hline Sonchus sp. & Asteraceae & Maas'olliya & $L, R$ & $\mathrm{H}$ & Pounding & 0 \\
\hline Calpurnia aurea (Ait.) Benth. & Fabaceae & Mayluwa & $\mathrm{R}$ & $S$ & Pounding & $\mathrm{Tp}, 0$ \\
\hline $\begin{array}{l}\text { Hypericum quartinianum } A \text {. } \\
\text { Rich. }\end{array}$ & Hypericaceae & Migiraa & $\mathrm{R}$ & $S$ & $\begin{array}{l}\text { Wash thoroughly } \\
\text { pounding }\end{array}$ & 0 \\
\hline
\end{tabular}

Page 18/23 


\begin{tabular}{|c|c|c|c|c|c|c|}
\hline Azadirachta indica & Meliaceae & Miimmiya mitsaa & $\mathrm{L}$ & $\operatorname{Tr}$ & Pounding & O, Tp \\
\hline Capsicum frutescens & Solanaceae & Mis'imis'uwa & $\mathrm{Sd}$ & $\mathrm{H}$ & $\begin{array}{l}\text { Pounding, enclosed in } \\
\text { the wilted inset leaf }\end{array}$ & 0 \\
\hline
\end{tabular}

\begin{tabular}{|c|c|c|c|c|c|c|}
\hline Plectranthus caninus & Lamiaceae & Mud'd'a/Gaalimentsuwa & L & $\mathrm{H}$ & $\begin{array}{l}\text { Wilt the leaf in the fire, } \\
\text { squeezing and tincture }\end{array}$ & $\mathrm{Tp}$ \\
\hline Ximenia caffra & Olacaceae & Mulahuwa & $\mathrm{R}$ & $\operatorname{Tr}$ & Pounding & 0 \\
\hline Syzygium guineen & Myrtaceae & Ochchaa & $\mathrm{Br}$ & $\operatorname{Tr}$ & Pounding & 0 \\
\hline
\end{tabular}

\begin{tabular}{|c|c|c|c|c|c|c|}
\hline Lobelia giberroa & Lobeliaceae & Odooduwa & $\mathrm{R}$ & $S$ & Pounding & $\mathrm{O}, \mathrm{N}$ \\
\hline Acacia sp. & Fabaceae & Odooruwa & $\mathrm{Br}$ & $\operatorname{Tr}$ & Pounding & 0 \\
\hline Rumex abyssinicus Jacq. & Polygnaceae & Oogi c'o'l”iya & $\mathrm{R}$ & $\mathrm{H}$ & Pounding & $\mathrm{O}, \mathrm{N}$ \\
\hline Pycnostachyus abyssinica & Lamiaceae & Olomuwa & $\mathrm{L}$ & $S$ & Pounding & 0 \\
\hline $\begin{array}{l}\text { Prunus africana (Hook. f) } \\
\text { Kalkm. }\end{array}$ & Rosaceae & Ontsaa & $\mathrm{Br}$ & $\operatorname{Tr}$ & $\begin{array}{l}\text { Pound and mix with } \\
\text { water }\end{array}$ & $\mathrm{Tp}$ \\
\hline Carica papaya & Caricaceae & Paappaa & $\mathrm{R}$ & S & Pounding & 0 \\
\hline Withania saminfera $L$. & Solanaceae & S'eemushaa & $\mathrm{L}, \mathrm{R}, \mathrm{Sm}$ & $\mathrm{H}$ & Pounding & O,N Fum/ \\
\hline
\end{tabular}

\begin{tabular}{|c|c|c|c|c|c|c|}
\hline Juniperus procera & Cuperssacae & S'iiddaa & $\mathrm{Sd}$ & $\operatorname{Tr}$ & Pounding & 0 \\
\hline Haplocarpa sp. & Asteraceae & S’okkaa d'aliya & $\mathrm{R}$ & $\mathrm{H}$ & Pounding & 0 \\
\hline $\begin{array}{l}\text { Becium obovatum (E.Mey. ex } \\
\text { Benth. in E. Mey.) N.E. Br. }\end{array}$ & Lamiaceae & Sa'a tuussaa/C'am'ashiya & $\mathrm{R}$ & $\mathrm{H}$ & Pound and mix with salt & $\mathrm{N}$ \\
\hline Vernonia karagnensis & Asteraceae & Saggaa & L & $\operatorname{Tr}$ & Pounding & 0 \\
\hline Maerue oblongifolia & Capparidaceae & Sangaanaa & $\mathrm{R}, \mathrm{Br}$ & S & Pounding & $\mathrm{O}, \mathrm{N}$, Aur \\
\hline
\end{tabular}

$\begin{array}{llllll}\text { Justica schimperiana } & \text { Acanthaceae } & \text { Sansalliya } & \text { L, R } & \text { S } & \text { Pounding } \\ \text { Indigofera spicata Forssk. } & \text { Fabaceae } & \text { Sheekkaa/Dangarsa k'uuruwa } & \text { R, Sm } & \text { H } & \text { Pounding }\end{array}$

\begin{tabular}{|c|c|c|c|c|c|c|}
\hline Brucea artidysentrica & Simaraubaceae & Shuushalliya & L, Sd & $\operatorname{Tr}$ & Pounding & $\mathrm{N}$ \\
\hline Lepidium satvum & Sibikkaa & $\mathrm{Sd}$ & $\mathrm{H}$ & $\begin{array}{l}\text { Grinding, mix } \\
\text { the seed with } \\
\text { butter and } \\
\text { direct } \\
\text { feeding(poultry) }\end{array}$ & 0 & $\begin{array}{l}\text { Blackleg, } \\
\text { disorder ( } \\
\text { Emaciatic } \\
\text { Mastitis, } \\
\text { Anthrax, I } \\
\text { Trypanos } \\
\text { Arthritis/l } \\
\text { Coccidios }\end{array}$ \\
\hline Hagnia abyssinica & Rosaceae & Soyd'uwa & Sd & $\operatorname{Tr}$ & $\begin{array}{l}\text { Put together with } \\
\text { Echinops kebericho on }\end{array}$ & Fum/Sk, \\
\hline
\end{tabular}

Page 19/23 
the fire

\begin{tabular}{|c|c|c|c|c|c|c|}
\hline Nicotiana tabacum & Solanaceae & Tambuwa & L & $\mathrm{H}$ & $\begin{array}{l}\text { Wilt on the sun/fire, } \\
\text { pounding, make a bread }\end{array}$ & $\mathrm{N}, \mathrm{O}$ \\
\hline Colocasia esculenta L. & Araceae & Teebbiya boynaa & $\mathrm{R}, \mathrm{L}$ & $\mathrm{H}$ & Pounding & $\mathrm{N}, \mathrm{O}$ \\
\hline $\begin{array}{l}\text { Glycine wightii } \\
\text { (Weight\&Anu)Verde }\end{array}$ & Fabaceae & Toogguwa turaa & L & $\mathrm{Cl}$ & Pounding & $\mathrm{N}$ \\
\hline Allium sativum & Alliaceae & Tuummuwa & $\mathrm{Bb}$ & $\mathrm{H}$ & Pounding & $0, N$ \\
\hline Piper capense & Piperaceae & Tunjaa & $\mathrm{Sd}$ & $\mathrm{H}$ & Pounding & 0 \\
\hline Oxytenanthera abyssinica & Poaceae & Uusuuntsaa & L & $S$ & Pounding & 0 \\
\hline Tagetes patula $L$. & Asteraceae & Wontik'amma/Derek'aa & L & $\mathrm{H}$ & Pounding & $\mathrm{Tp}$ \\
\hline Arundinaria alpine & Poaceae & Wooshshaa & L & $\mathrm{S}$ & Pounding & 0 \\
\hline Solanum anguiv anguivi Lam. & Solanaceae & Wora buluwa & $\mathrm{Fr}$ & $\mathrm{H}$ & $\begin{array}{l}\text { Chop the ripped one with } \\
\text { sharp knife, remove seed } \\
\text { through straining and } \\
\text { use fruit fluid }\end{array}$ & $\mathrm{N}, \mathrm{O}$ \\
\hline Zingiber officinale & Zingiberaceae & Yanjeeluwa & $\mathrm{Rm}$ & $\mathrm{H}$ & Pounding & $\mathrm{N}, \mathrm{O}$ \\
\hline $\begin{array}{l}\text { Gnidia involucrata Steud ex A. } \\
\text { Rich. }\end{array}$ & Thymelaeaceae & Yesheeshshuwa & $\mathrm{R}$ & $\mathrm{H}$ & Pounding & $\mathrm{O}, \mathrm{N}$ \\
\hline $\begin{array}{l}\text { Eucalphytus camaldulencis } \\
\text { Dehnh }\end{array}$ & Myrtaceae & Zo'o balizaafiya & L & $\operatorname{Tr}$ & Pounding & $\mathrm{O}, \mathrm{N}, \mathrm{Tp}$ \\
\hline Ricccinus communis & Euphorbiaceae & Zo’o S'eemaa & $\mathrm{R}$ & $S$ & $\begin{array}{l}\text { Wash thoroughly, } \\
\text { pounding }\end{array}$ & 0 \\
\hline Allium сера & Alliaceae & Sunk'uruutuwa & $\mathrm{Bb}$ & $\mathrm{H}$ & Pounding & 0 \\
\hline $\begin{array}{l}\text { Bridelia micrantha (Hochst.) } \\
\text { Baill. }\end{array}$ & Euphorbiaceae & Zuuziya & $\mathrm{R}, \mathrm{Br}$ & $\operatorname{Tr}$ & Pounding & $\mathrm{N}$ \\
\hline Dichondra repens & Convolvulacaeae & Ec'ere haytsa & $\mathrm{R}$ & $\mathrm{H}$ & $\begin{array}{l}\text { Pound together with root } \\
\text { of Indigofora spicata, } \\
\text { Sonchus sp. and Acacia } \\
\text { sp. leaf }\end{array}$ & 0 \\
\hline $\begin{array}{l}\text { Pentas lanceolata (Forssk.) } \\
\text { Defiers }\end{array}$ & Rubaceae & Shid'i bid'aa & $\mathrm{R}$ & $\mathrm{H}$ & Pounding & 0 \\
\hline
\end{tabular}

Key: Plant parts; L = Leaf, $\mathrm{R}=$ Root, $\mathrm{Bb}=$ Bulb, $\mathrm{Br}=$ Bark, $\mathrm{Sm}=\mathrm{Stem}, \mathrm{Wp}=$ Whole plant, $\mathrm{Sd}=\mathrm{Seed}, \mathrm{Fr}=$ Fruit, $\mathrm{Rm}=\mathrm{Rhizome}$,

Plant types; $\mathrm{H}=$ Herb, $\mathrm{Tr}=$ Tree, $\mathrm{S}=$ Shrub, $\mathrm{Cl}=$ Climber

Routes; $\mathrm{O}=$ Oral, $\mathrm{N}=$ Nasal, $\mathrm{Tp}=$ Topical, Fum/sk=Fumigate/smoking, Aur $=$ Auricular

Table $\mathbf{3}$ List of ethnoveterinary medicinal plants for treatment of non-infectious diseases, ectoparasites infestations and miscellaneous livestock health management in Tocha, Mareka and Loma districts of Dawuro zone 


\begin{tabular}{|c|c|c|c|c|c|c|c|c|}
\hline Family name & $\begin{array}{l}\text { Scientific } \\
\text { name }\end{array}$ & Local name & Part & $\begin{array}{l}\text { Plant } \\
\text { type }\end{array}$ & Preparations & Route & Veterinary uses & $\begin{array}{l}\text { Use- } \\
\text { value }\end{array}$ \\
\hline Vigna sp. & Fabaceae & Bak'aliya haytsaa & $\mathrm{L}$ & $\mathrm{Cl}$ & Pounding & 0 & Leech & 0.035 \\
\hline $\begin{array}{l}\text { Nephrolepsis } \\
\text { undulata }\end{array}$ & Olendraceae & Bisaa & $\mathrm{L}$ & $\mathrm{H}$ & $\begin{array}{l}\text { Cutting the leaf and } \\
\text { place on the barn as } \\
\text { bedding }\end{array}$ & $\begin{array}{l}\text { as } \\
\text { bedding }\end{array}$ & Tick expulsion & 0.02 \\
\hline $\begin{array}{l}\text { Clerodendrum } \\
\text { cordifolium }\end{array}$ & Lamiaceae & Boyye maataa & L & $\mathrm{Cl}$ & Pounding & $\mathrm{N}$ & Leech & 0.026 \\
\hline Cofe arabica & Rubiaceae & Bunaa/tukkiya haytsaa & L & S & $\begin{array}{l}\text { Pounding and boil, } \\
\text { decoction }\end{array}$ & 0 & $\begin{array}{l}\text { Retained Placenta, } \\
\text { Fattening }\end{array}$ & 0.026 \\
\hline Sida rhombifolia $L$. & Malvaceae & Danduretsaa & $\begin{array}{l}\mathrm{L} \\
\mathrm{Sm}\end{array}$ & $\mathrm{H}$ & Pounding & 0 & $\begin{array}{l}\text { Fattening, } \\
\text { Constipation }\end{array}$ & 0.02 \\
\hline Pentas shimperiana & Rubiaceae & Dawuridamaa/Dalbantsaa & $\stackrel{L}{S}$ & S & Pounding & 0 & $\begin{array}{l}\text { Fattening, Bone } \\
\text { broken, Appetizer, } \\
\text { Constipation }\end{array}$ & 0.17 \\
\hline $\begin{array}{l}\text { Maessa lanceolata } \\
\text { Forssk. }\end{array}$ & Myrsinaceae & Geggec'uwa & $\begin{array}{l}L_{1} \\
S d\end{array}$ & $\operatorname{Tr}$ & Pounding, grinding & 0 & Leech & 0.07 \\
\hline Entada abyssinica & Fabaceae & Gelc'eec'aa & L & $\operatorname{Tr}$ & Dried, powdering & Tp, N & Wound, Leech & 0.04 \\
\hline $\begin{array}{l}\text { Gnewia mollis } \\
\text { A.Juss }\end{array}$ & Tiliaceae & Gomariya/Monok'uwa & $\mathrm{Br}$ & $\operatorname{Tr}$ & $\begin{array}{l}\text { Enclose the bark } \\
\text { with fiber and pound } \\
\text { and then mix water }\end{array}$ & 0 & $\begin{array}{l}\text { Constipation, } \\
\text { Removal of foreign } \\
\text { material }\end{array}$ & 0.069 \\
\hline $\begin{array}{l}\text { Ensete ventricosum } \\
(\text { Welw.).cheeman }\end{array}$ & Musaceae & Looc'ingiya uutsaa & L & $\mathrm{S}$ & $\begin{array}{l}\text { Chopped, direct } \\
\text { feeding }\end{array}$ & 0 & Retained placenta & 0.05 \\
\hline $\begin{array}{l}\text { Brassica carinata } \\
\mathrm{A} . \mathrm{Br}\end{array}$ & Brassicaceae & Maas'iya santsaa & L & $\mathrm{H}$ & Direct feeding & 0 & Retained placenta & 0.03 \\
\hline $\begin{array}{l}\text { Cynoglossum } \\
\text { coeruleum } \\
\text { Hochst.exA.DC.in } \\
\text { DC }\end{array}$ & Boraginaceae & Shiddo & $\mathrm{Sd}$ & $\mathrm{H}$ & $\begin{array}{l}\text { Collect the ripped } \\
\text { seed, squeezing and } \\
\text { apply on } \\
\text { contaminated } \\
\text { wound, pound }\end{array}$ & Tp & $\begin{array}{l}\text { Contaminated } \\
\text { wound, Tick }\end{array}$ & 0.02 \\
\hline Plectranthus sp. & Lamiaceae & Shooggaa/Shuyk'aa & Wp & $\mathrm{H}$ & Pounding & 0 & $\begin{array}{l}\text { Fattening, body } \\
\text { building (Emaciation) }\end{array}$ & 0.03 \\
\hline $\begin{array}{l}\text { Linum } \\
\text { usitatissimum }\end{array}$ & Linaceae & Talbaa & $\mathrm{Sd}$ & $\mathrm{H}$ & Grinding & 0 & $\begin{array}{l}\text { Constipation, } \\
\text { Emaciation/Fattening }\end{array}$ & 0.03 \\
\hline $\begin{array}{l}\text { Lycopersicon } \\
\text { esculentum mill }\end{array}$ & Solanaceae & Timaatimiya & L & $\mathrm{H}$ & Pounding & $\mathrm{N}$ & Leech & 0.02 \\
\hline $\begin{array}{l}\text { Millettia ferruginea } \\
\text { (Hochst.) Bak. }\end{array}$ & Fabaceae & Zaagiya & L & $\operatorname{Tr}$ & $\begin{array}{l}\text { Pound and place on } \\
\text { the river overnight } \\
\text { and remove at } \\
\text { morning }\end{array}$ & Tp & Leech, Tick & 0.03 \\
\hline
\end{tabular}

Key: Plant parts; L= Leaf, $\mathrm{Br}=$ Bark, Sm = Stem, $\mathrm{Wp}=$ Whole plant, $\mathrm{Sd}=\mathrm{Seed}$, Plant types; $\mathrm{H}=\mathrm{Herb}, \mathrm{Tr}=\mathrm{Tree}, \mathrm{S}=\mathrm{Shrub}, \mathrm{Cl}=\mathrm{Climber}, \mathrm{Routes} ; \mathrm{O}=\mathrm{Oral}, \mathrm{N}=$ Nasal, $T p=$ Topical

Table 6 Results of preference ranking of medicinal plants reported for treating Blackleg

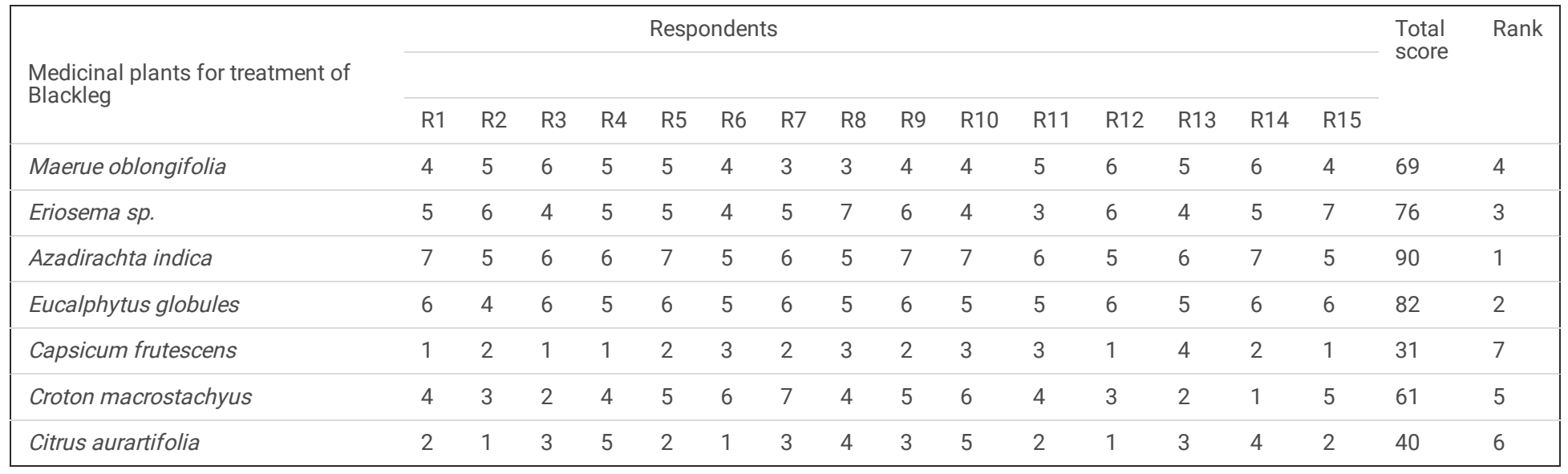

$\mathrm{R}=$ Respodents 


\section{Figures}

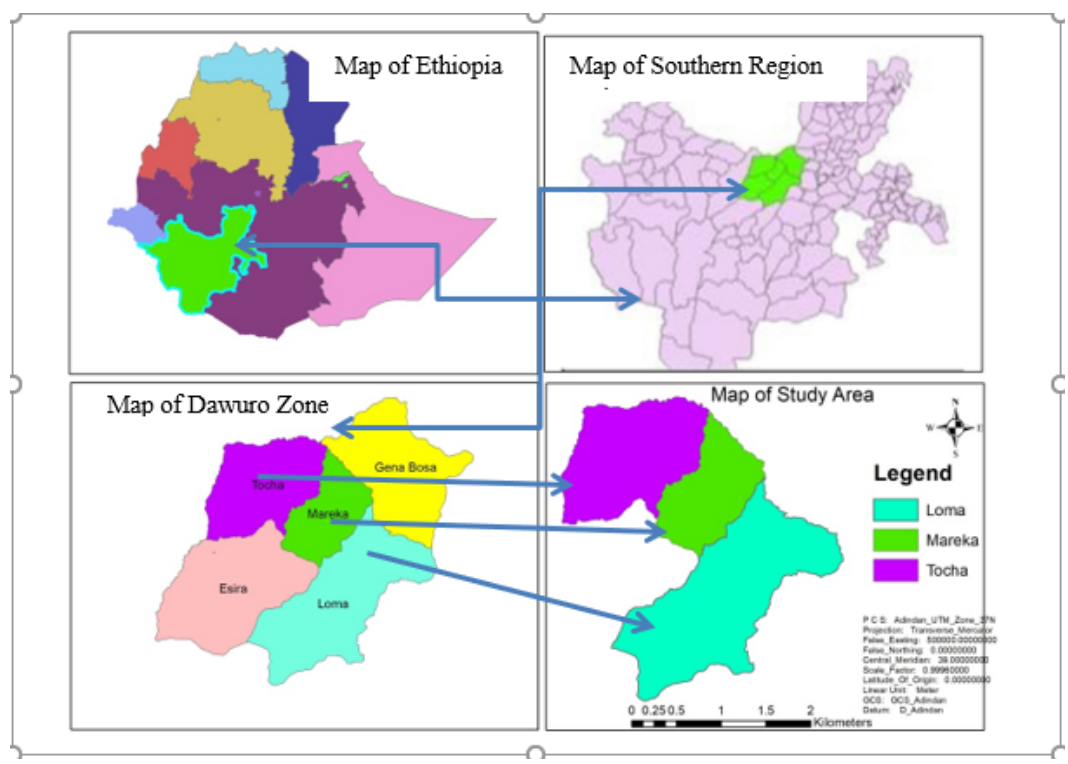

Figure 1

Study area map Note: The designations employed and the presentation of the material on this map do not imply the expression of any opinion whatsoever on the part of Research Square concerning the legal status of any country, territory, city or area or of its authorities, or concerning the delimitation of its frontiers or boundaries. This map has been provided by the authors.

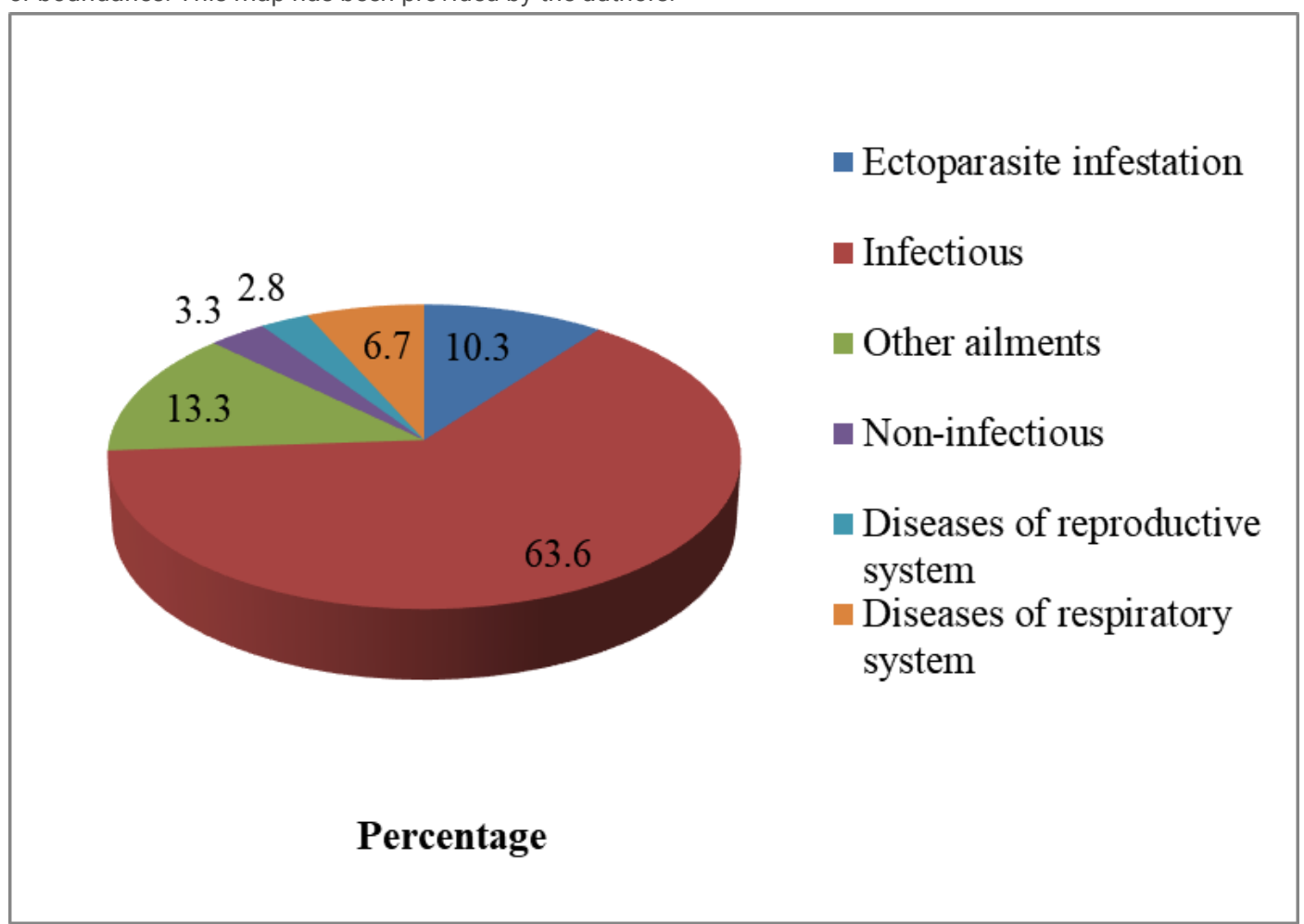

Figure 2

Livestock disease categories treated in the study area 


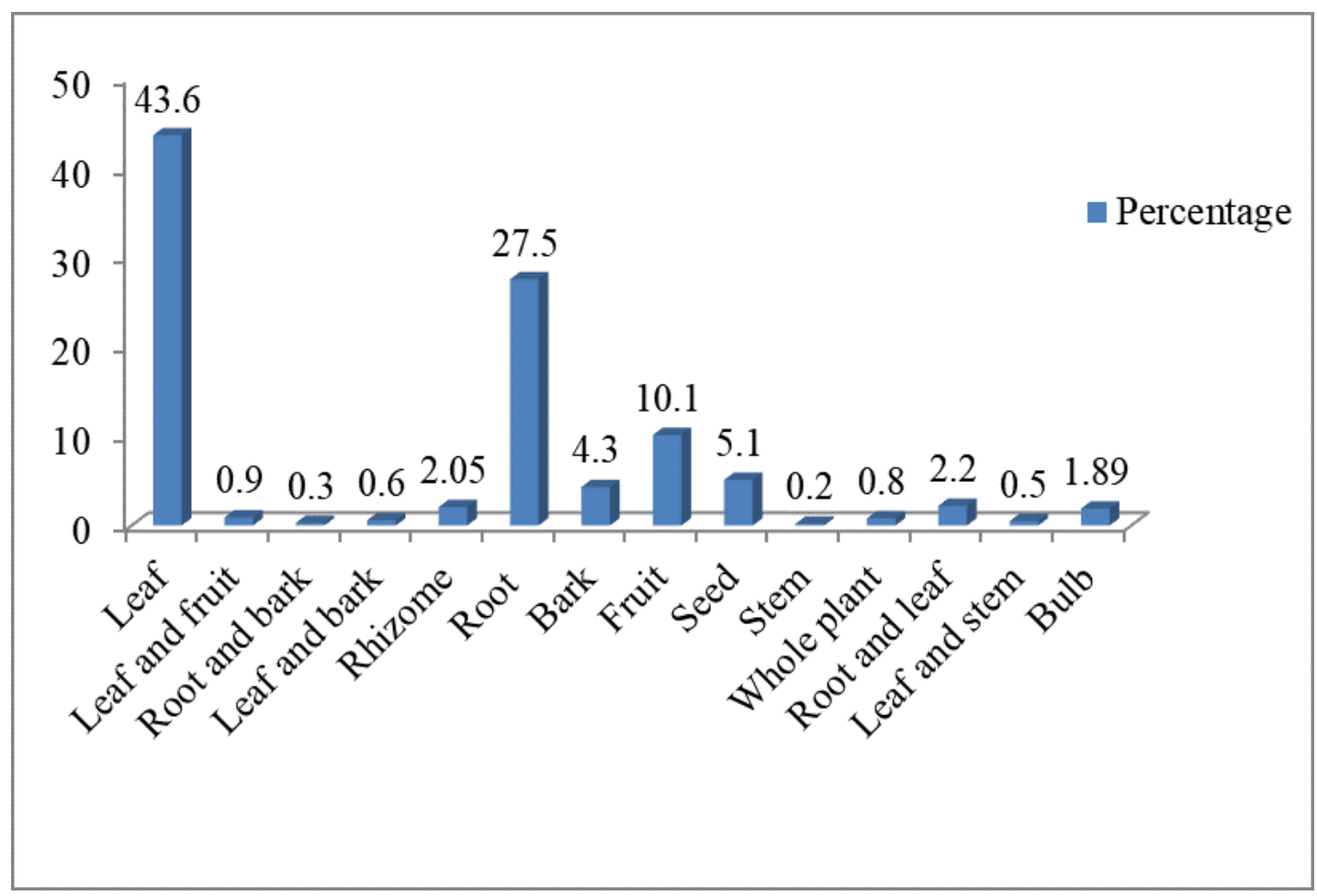

Figure 3

Percentage of different parts of plants for remedy preparation in Dawuro zone

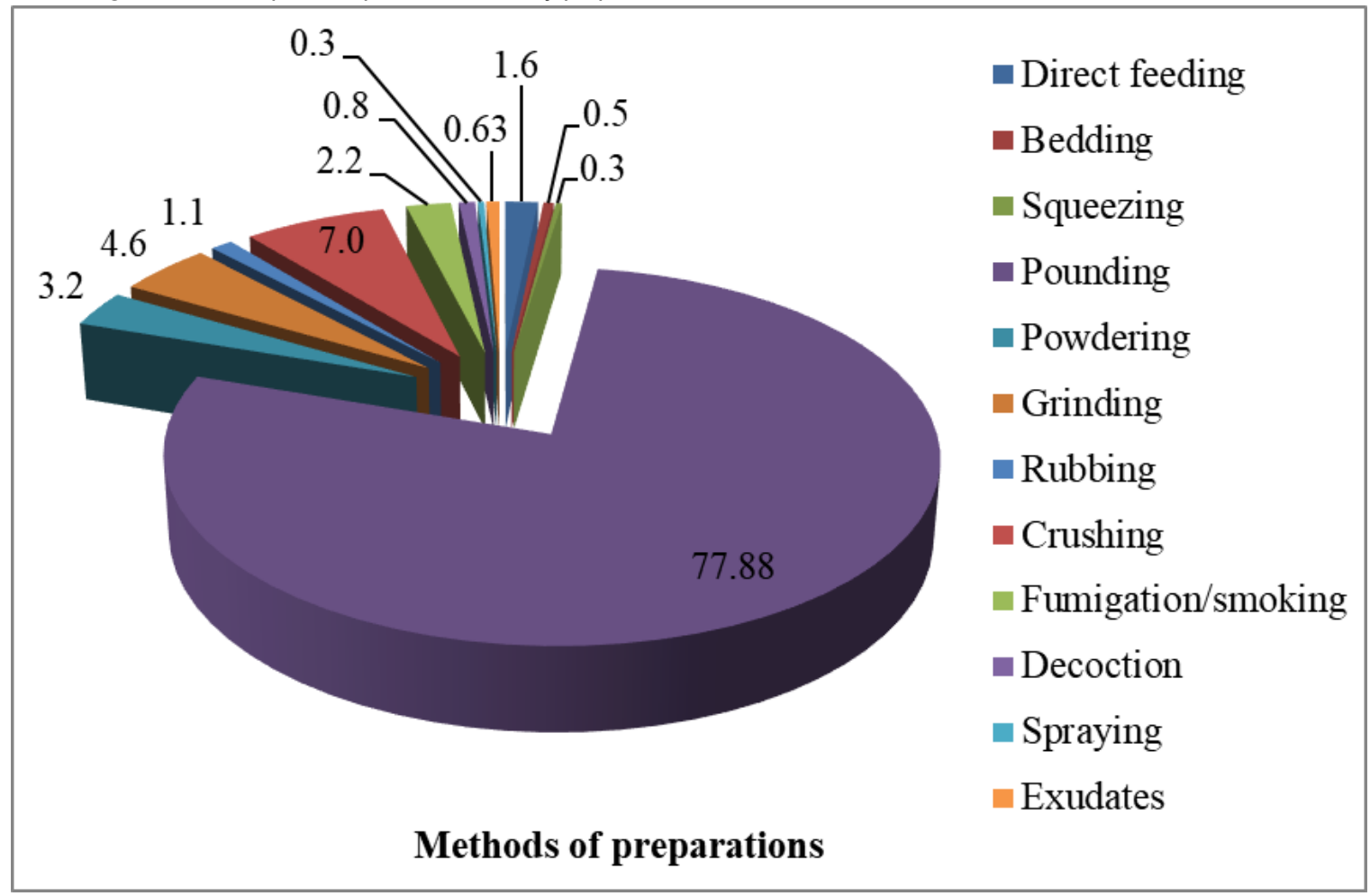

Figure 4

Methods of treatment preparation in the study area 